\title{
Investor Characteristics and their Impact on the Decision to use a Robo-advisor
}

\author{
Andreas Oehler ${ }^{1}$ D $\cdot$ Matthias Horn ${ }^{2} \cdot$ Stefan Wendt ${ }^{3}$
}

Received: 10 November 2020 / Revised: 4 October 2021 / Accepted: 4 October 2021 /

Published online: 27 December 2021

(c) The Author(s) 2021, corrected publication 2022

\begin{abstract}
We survey 231 undergraduate students to analyze how retail investors' characteristics influence their decision to use a robo-advisor. Characteristics such as the willingness to take risk, extraversion, and optimism are significant in univariate tests but the willingness to take risk and the internal locus of control are significant in multivariate settings. Participants who use the robo-advisor invest more and are more likely to also invest on their own in both stocks and bonds. We also find statistically significant differences between participants who exclusively use the robo-advisor for investments in stocks and bonds and participants who use the robo-advisor and invest some money in stocks and bonds on their own.
\end{abstract}

Keywords Robo-advisor · Financial Advice · Portfolio Management · Investments · Personal Finance $\cdot$ Household Finance

JEL Codes D14 · G11 $\cdot$ G24 $\cdot$ G29

\begin{abstract}
We would like to thank Haluk Ünal (Editor-in-Chief), Nagpurnanand Prabhala (Co-Editor), an anonymous referee, participants of the International Conference on Operations Research 2021, participants of the Behavioural Finance Working Group Conference 2021, and participants of the Psychonomic Society 2020 Annual Meeting for valuable comments and suggestions. A previous version of the paper has been presented under the title "Do Robo-Advisors Address Less Risk-Averse People?". All remaining errors are our own.
\end{abstract}

Andreas Oehler

andreas.oehler@uni-bamberg.de

1 Bamberg University, Kaerntenstrasse 7, 96045 Bamberg, Germany

2 Department of Finance, Bamberg University, Bamberg, Germany

3 Department of Business, Bifröst University, Bifröst, Iceland 


\section{Introduction}

In this study, we analyze how retail investors' individual characteristics influence their decision to invest through a robo-advisor. The most popular robo-advisors for investors propose an investment portfolio that typically consists of stock and bond index funds (Horn and Oehler 2020). ${ }^{1}$

One of the potential advantages of robo-advisors over more traditional investment advice is their 24/7 availability. This increased flexibility regarding time engenders lower consultation costs that makes robo-advisors interesting to low net-wealth individuals (D’Acunto and Rossi 2020; Horn et al. 2020; Rossi and Utkus 2020b). Moreover, roboadvisors can help investors who might not have private information build well-diversified portfolios with little behavioral biases that are typical of human advisors (see Linnainmaa et al. 2020, Foerster et al. 2017, Inderst and Ottaviani 2009). Robo-advisors can mitigate biases because they follow predefined rules (see D'Acunto et al. 2019).

The sum of all robo-advisors' assets under management in the year 2020 was only 1.07 trillion USD. ${ }^{2}$ This is a small amount when compared to the assets under management of the largest asset managers such as BlackRock (8.7 trillion USD), Vanguard (7.2 trillion USD), and State Street (3.5 trillion USD). Furthermore, at least 15 asset management firms had more assets under management individually than all robo-advisors combined. ${ }^{3}$ Beyond the recency of robo-advising (Fisch et al. 2019), explanations for the relatively low assets under management and low inflows remain unclear. Hohenberger et al. (2019) find that retail investors who associate the use of a robo-advisor with joy are more likely to use it. Rossi and Utkus (2020a) show that one main reason to avoid robo-advisors is the lack of possibilities for personal communication and a lack of trust. Specifically, investors who trust their human financial advisor are very unlikely to use a robo-advisor.

We conducted a questionnaire-based survey of 231 undergraduate business students at a German medium-sized university in November 2019 to analyze the influence of individual characteristics on the decision to use robo-advising. Our reasoning is that there is a higher probability that young adults will use a robo-advisor than older adults. Young adults are less subject to algorithm aversion (Rossi and Utkus 2020a). They have no relationship or a less established and less trust-based relationship with a human advisor. Moreover, young adults are a very important target group for robo-advisors. A survey of young adults is thus also useful for the practice of robo-advisory.

In the survey we use validated questionnaire items to measure the characteristics that potentially influence investment decisions such as gender, financial knowledge, statistical knowledge, risk attitude, cognitive reflection, Big Five personality factors, locus of control, PANAS, and trust in institutions and persons other than a human financial advisor (see the overviews in, e.g., Oehler et al. 2018a, Oehler et al. 2020, Oehler et al. 2021, and Oehler and Wendt 2018). The literature shows that the majority of these characteristics also

\footnotetext{
${ }^{1}$ Examples for robo-advisors include: Betterment (USA), MoneyFarm (UK), Nutmeg (UK), Quirion (Germany), Scalable Capital (Germany), Schwab Intelligent Portfolios (USA), Wealthfront (USA). Some roboadvisors also provide recommendations regarding individual stocks (see, e.g., D'Acunto et al. 2019). We do not analyze this type of robo-advising.

${ }^{2}$ See https://www.statista.com/outlook/dmo/fintech/personal-finance/robo-advisors/worldwide\#assetsunder-management.

3 See https://www.blackrock.com/corporate/literature/annual-report/blackrock-2020-annual-report.pdf, https://about.vanguard.com/who-we-are/fast-facts/, https://annualreport.statestreet.com/Y2020/default.aspx, https://www.statista.com/statistics/322452/largest-asset-managers-worldwide-by-value-of-assets/.
} 
influence technology acceptance (Behrenbruch et al. 2013; see also Rossi and Utkus 2020a on the influence of algorithm aversion). Usually, more conscientious, less neurotic people with more technology experience, confidence, and trust in technology are more likely to use a new technology (Barnett et al. 2015; Lee et al. 2017).

Our participants receive a fixed participation fee that mitigates any incentive to gamble. Further, we do not provide a concrete investment suggestion in order to sidestep participants' confirmation bias (see Alemanni et al. 2020). This approach also eliminates the potential for a hypothetical bias as described in Cummings et al. (1997). However, the participants' answers are not financially binding in any case. The potential downside of using a survey approach is its external validity. Our findings only apply to likely users of robo-advisors and not to the entire population. But Oehler et al. (2018b) perform a survey of German undergraduate students on their financial portfolio choices, and Oehler et al. (2018c) use a comparable subset from the representative survey data of the German central bank. The results of both suggest that our findings have broader relevance.

Even young adults might perceive robo-advisors as less trustworthy than a human advisor. We hypothesize that the young adults in our survey with individual characteristics such as higher levels of extraversion, openness to new experiences, and optimism are more likely to be less risk averse and to use a robo-advisor. Presumably, not everyone among the individuals who give the robo-advisor a chance will go all-in and only use it for investing. Therefore, we allow participants to invest only a share or nothing at all of their investable wealth and to invest in risk-free to relatively risky asset classes that match their risk attitude.

Based on tests of equality, we find that participants who are willing to use the roboadvisor are more willing to take financial risks, are more extraverted, are more optimistic, and are less pessimistic than participants who are not willing to use the robo-advisor. ${ }^{4}$ These are key variables used in the literature and our results are in line with its findings (Dohmen et al. 2011, Oehler et al. 2018a, Puri and Robinson 2007; see also Kaustia et al. 2019 for an overview). When integrating all characteristics into a logit regression, the participants' willingness to take financial risks remains statistically significant but extraversion, optimism, and pessimism do not. Instead, participants with a lower internal locus of control are significantly more likely to use the robo-advisor (although the locus of control is not significant in the univariate analysis). Moreover, participants who are willing to use the robo-advisor invest a larger amount in stocks and bonds than participants who are not willing to use the robo-advisor, which is in line with the idea that those willing to use the robo-advisor are more willing to take financial risks.

We also find statistically significant differences between participants who exclusively use the robo-advisor for investments in stocks and bonds and participants who use the robo-advisor and invest some additional money on their own. The latter group invests more in stocks and bonds in total. However, the amount that they invest via the robo-advisor is less than the amounts invested by participants who exclusively use the robo-advisor. The participants who use the robo-advisor and invest in stocks and bonds on their own have higher levels of perceived financial knowledge and experience than participants who exclusively use the robo-advisor. These results are further support for the findings in the literature that more experienced and literate investors are more likely to invest higher amounts

\footnotetext{
${ }^{4}$ Optimism and pessimism are not considered as the two poles of one scale but as two independent factors (see Glaesmer et al. 2008).
} 
and shares of their wealth in risky assets and establish better diversified portfolios (van Rooij et al. 2011; Graham et al. 2009; von Gaudecker 2015).

However, we observe an inverse relation between the perceived statistical knowledge and the likelihood to invest additionally in stocks and bonds when using a robo-advisor. A multinomial regression supports our univariate findings for the effect of statistical knowledge and shows that participants who use the robo-advisor and invest in stocks and bonds on their own are less optimistic but more willing to take financial risks. Further, they have a lower internal locus of control than participants who exclusively invest with the roboadvisor. However, the results of our analysis do not indicate that any of the characteristics actually influence the difference in the amount that these two groups of participants invest with the robo-advisor.

Our findings provide implications for researchers and for providers of investment services and financial advice. For example, research on retail investors' investment decisions and on financial intermediation should consider that not only individuals' risk attitude in the financial domain but also that other individual characteristics might significantly influence decisions on which asset classes to invest in and at the same time which investment advisor to use.

The paper is structured as follows: We describe our survey design and our empirical methods in the next section. In Sect. 3, we present the empirical results. We discuss our findings and conclude in Sect. 4.

\section{Design and Methodology}

\subsection{Survey Design}

The participants received information gathered from the homepage of a real robo-advisor. This information covered an explanation of the robo-advisor's basic functionality, past returns, costs, risks, and advantages. ${ }^{5}$ Thereafter, the participants were given 1,000 Euros to invest. Other studies have used investable amounts that range from a few Euros (see Alemanni et al. 2020) to 10,000 Euros (see Nosic and Weber 2010). We chose an amount that presumably best reflected what students usually would handle. Furthermore, Oehler et al. (2018c) measured students' risk attitude in a theoretical lottery design with different Euro amounts and showed that students' answers reflected a reasonable degree of risk aversion; that is, students did not act as if they perceived the investment task as gambling with play money when the theoretical amount at stake was 500 Euros or more. Therefore, our choice seemed plausible given students' lifestyles and earning compacity.

The investment task was structured as follows: First, participants indicated whether they were willing to use the robo-advisor to invest (a share of) the 1,000 Euros or not. If participants were willing to use the robo-advisor, they stated the amount of money that they would invest out of the 1,000 Euros with the robo-advisor. In addition, they indicated the allocation to stocks and bonds (on a scale of $10 \% / 90 \%, 20 \% / 80 \%$, and so on) that the roboadvisor should follow for the portfolio. One condition was that our participants could only invest up to the 1,000 Euros because we did not allow them to borrow more money. For

\footnotetext{
5 We did not pick a robo-advisor with particularly good or bad past performance. See the return and risk information that respondents received in the Internet Appendix (p. 7 of the questionnaire).
} 
Table 1 Overview and descriptions of variables used in the empirical analysis

Vector/Variable Description

Panel A: Participants' characteristics

$C R T_{i}$

$G E N D E R_{i}$

LOTTERY_RISKY

LOTTERY_UNCERTAIN ${ }_{i}$

RISK_ATTITUDE

PANAS

NEGAFFECT $T_{i}$

POSAFFECT $_{i}$

KNOWLEDGE

KNOWLEDGE_STATISTICS ${ }_{i}$

SCORE_FIN_KNOW

LOCUS_OF_CONTROL

EXTLOCUS $_{i}$

INTLOCUS $_{i}$
Cognitive reflection that is measured by the sum of correct answers to six slightly transformed questions similar to those suggested by Primi et al. (2016) and three questions of Frederick (2005)

Dummy variable that equals one when participant $i$ is female and zero otherwise

Amount of money a participant is willing to pay for participation in the risky lottery proposed by Guiso et al. (2008)

Amount of money a participant is willing to pay for participation in the uncertain lottery proposed by Guiso et al. (2008)

Self-assessment of risk attitude in the financial domain on an 11-point Likert scale (from 0 to 10) based on Dohmen et al. (2011)

Negative affect that is determined as the median value of three items based on a scale from one to five on the German version of the PANAS by Krohne et al. (1996)

Positive affect that is determined as the median value of three items on a scale from one to five based on the German version of the PANAS by Krohne et al. (1996)

Self-assessment about statistical knowledge on a 6-point Likert scale (from " 1 - very good" to " 6 - very poor", based on the German school grading scale) based on Glaser et al. (2007). For the empirical analysis, inverted values are used so that one indicates very poor statistical knowledge and six very good statistical knowledge

Financial knowledge determined as sum of two items based on Abreau/Mendes (2012). One item asks participant to name five stocks listed in the German blue-chip index DAX, the other item asks about the authority responsible for complaints about miscounseling in financial advice in Germany. Participants can get five points for each item. One point for every correct stock in the DAX and five points for the correct authority. Hence, the value of SCORE_FIN_KNOW $W_{i}$ can range from 0 to 10 . A value of 0 means that the participant provided no correct answer. A value of 10 means that the participant answered all questions correctly

External locus of control that is determined as the median value of two items on a scale from one to five based on Kovaleva et al. (2012)

Internal locus of control that is determined as the median value of two items on a scale from one to five based on Kovaleva et al. (2012) 
Table 1 (continued)

\begin{tabular}{lc}
\hline Vector/Variable & Description \\
\hline AGREEABLENESS & \\
& $\begin{array}{c}\text { Agreeableness that is determined as the median value of } \\
\text { two items on a scale from one to five based on the BFI- } \\
10 \text { of Rammstedt et al. (2012) } \\
\text { Conscientiousness that is determined as the median value } \\
\text { of two items on a scale from one to five based on the }\end{array}$ \\
BFI-10 of Rammstedt et al. (2012)
\end{tabular}

$E_{\text {ETRAVERT }}$

NEUROTICISM $_{i}$

OPENNESS $_{i}$

LIFE_ORIENTATION

LIFE_ORIENTATION_OPTIMISM ${ }_{i}$

LIFE_ORIENTATION_PESSIMISM

FINANCIAL_ADVICE

PERSONAL_FINANCIAL_ADVICE

ROBO_FINANCIAL_ADVICE

EXPERIENCE_STOCKS

EXPERIENCE_STOCK_MARKET

EXPERIENCE_STOCK_MARKET_SATISFIED ${ }_{i}$ Satisfactory results in the stock market that are determined by the answer to the question "Would you say that your recent stock market transactions had satisfactory results?" on a scale from one (no, not at all) to five (yes, completely); enters the regression analysis as an interaction term EXPERIENCE_STOCK_ $M A R K E T_{i}{ }^{*} E X P E R I E N C E \_S T O C K \_M A R K E T \_S A T I S-$ FIED $_{i}$

TRUST

CONFIDENCE

Confidence that is determined by the answer to the question "How often do you leave the front door unlocked?" on a scale from one to five based on Fehr et al. (2002) and SOEP (2003) 
Table 1 (continued)

\begin{tabular}{ll}
\hline Vector/Variable & Description \\
\hline TRUST_AUTHORITIES_GENERAL $i$ & $\begin{array}{c}\text { Trust in authorities in general is a scale that ranges from } \\
\text { one (no trust at all) to four (high trust), based on Fehr } \\
\text { et al. (2002) and SOEP (2003) }\end{array}$ \\
TRUST_AUTHORITIES_FINANCIAL $L_{i}$ & Trust in financial authorities is a scale that ranges from \\
& one (no trust at all) to four (high trust) \\
TRUST_COURTS & Trust in courts is a scale that ranges from one (no trust \\
& at all) to 4 (high trust), based on Fehr et al. (2002) and \\
& SOEP (2003)
\end{tabular}

TRUST_FINANCIAL_SERVICE_PROVIDERS $S_{i} \quad$ Trust in financial service providers is a scale that ranges from one (no trust at all) to four (high trust), based on Fehr et al. (2002) and SOEP (2003)

TRUST_FRIENDS_GENERAL $L_{i}$

TRUST_FRIENDS_MONETORY $Y_{i}$

TRUST_FRIENDS_NON-MONETORY ${ }_{i}$

Trust in friends in general is a scale that ranges from one (no trust at all) to four (high trust), based on Fehr et al. (2002) and SOEP (2003)

Trust in friends in monetary issues that is determined by the answer to the question "How often do you lend your friends money?" on a scale from one to five based on Fehr et al. (2002) and SOEP (2003)

Trust in friends in non-monetary issues that is determined by the answer to the question "How often do you lend your friends personal items (e.g. books, your car, your bike, etc.)?" on a scale from one to five based on Fehr et al. (2002) and SOEP (2003)

TRUST_OTHER_PEOPLE

Trust in other people; dummy variable that equals one when participants state that most people can be trusted and zero otherwise, based on Guiso et al. (2008) and Fehr et al. (2002)

TRUST_POLICE

TRUST_PRESS

TRUST_STIFTUNG_WARENTEST $T_{i}$

Panel B: Investment Decisions

AMOUNT_INVESTED_IN_

STOCKS_BONDS_FUND $\bar{S}_{i}$

INVEST_WITH_ROBO

INVEST_WITH_ROBO_AMOUNT

INVEST_WITH_ROBO_STOCK_RATIO ${ }_{i}$

INVEST_WITHOUT_ROBO_AMOUNT ${ }_{i}$

Trust in the police is a scale that ranges from one (no trust at all) to four (high trust), based on Fehr et al. (2002) and SOEP (2003)

Trust in the press is a scale that ranges from one (no trust at all) to four (high trust), based on Fehr et al. (2002) and SOEP (2003)

Trust in the German consumer organization "Stiftung Warentest" is a scale that ranges from one (no trust at all) to four (high trust)

The amount of money invested in stocks, bonds, and funds covering stocks and bonds

Investment with robo-advisor; dummy variable that equals one when participants state that they are willing to invest with the robo-advisor and zero otherwise

Amount of money a participant is willing to invest with the robo-advisor; conditional on INVEST_WITH_ $R O B O$ equaling one

Stock ratio that a participant selects for the investment with the robo-advisor

Amount of money a participant is willing to invest in stocks, bonds, and funds covering stocks and bonds without the robo-advisor

Amount of money a participant is willing to invest in balanced mutual funds without the robo-advisor 
Table 1 (continued)

\begin{tabular}{|c|c|}
\hline Vector/Variable & Description \\
\hline $\begin{array}{l}\text { INVEST_WITHOUT_ROBO_AMOUNT } \\
\text { BOND INDEX FUNDS }\end{array}$ & $\begin{array}{l}\text { Amount of money a participant is willing to invest in } \\
\text { bond index funds without the robo-advisor }\end{array}$ \\
\hline $\begin{array}{l}\text { INVEST_WITHOUT_ROBO_AMOUNT } \\
\text { BOND MUTUAL FUNDS }\end{array}$ & $\begin{array}{l}\text { Amount of money a participant is willing to invest in } \\
\text { bond mutual funds without the robo-advisor }\end{array}$ \\
\hline $\begin{array}{l}\text { INVEST_WITHOUT_ROBO_AMOUNT } \\
\text { INDIVIDUALBONDS }\end{array}$ & $\begin{array}{l}\text { Amount of money a participant is willing to invest in } \\
\text { individual bonds without the robo-advisor }\end{array}$ \\
\hline $\begin{array}{l}\text { INVEST_WITHOUT_ROBO_AMOUNT } \\
\text { INDIVIDUALSTOCKS }\end{array}$ & $\begin{array}{l}\text { Amount of money a participant is willing to invest in } \\
\text { individual stocks without the robo-advisor }\end{array}$ \\
\hline $\begin{array}{l}\text { INVEST_WITHOUT_ROBO_AMOUNT } \\
\text { STOCK INDEX FUNDS }\end{array}$ & $\begin{array}{l}\text { Amount of money a participant is willing to invest in } \\
\text { stock index funds without the robo-advisor }\end{array}$ \\
\hline $\begin{array}{l}\text { INVEST_WITHOUT_ROBO_AMOUNT_ } \\
\text { STOCK MUTUAL FUNDS }\end{array}$ & $\begin{array}{l}\text { Amount of money a participant is willing to invest in } \\
\text { stock mutual funds without the robo-advisor }\end{array}$ \\
\hline$I N V E S T \_W I T H O U T \_R O B O \_S T O C K \_R A T I O_{i}$ & $\begin{array}{l}\text { Stock ratio that a participant selects for the investments } \\
\text { in stocks, bonds, and funds covering stocks and bonds } \\
\text { without the robo-advisor }\end{array}$ \\
\hline$S O L E L Y \_U S I N G \_R O B O_{i}$ & $\begin{array}{l}\text { Dummy variable that equals one when participants state } \\
\text { that they are willing to invest solely with the robo- } \\
\text { advisor and zero otherwise }\end{array}$ \\
\hline
\end{tabular}

the amount that they did not invest with the robo-advisor, participants were asked to state the amounts that they had invested in liquidity provisions, fixed-term deposits, bond ETFs, stock ETFs, real estate funds, bond mutual funds, stock mutual fonds, individual bonds and stocks, and/or another asset class. Hence, participants could design portfolios on a continuum ranging from almost risk-free in liquid assets to fairly risky (with or without the robo-advisor) in individual stocks or even options or certificates.

Additionally, the questionnaire included items to capture the individual characteristics of the participants. An overview of the variables used in the empirical analysis, how they are measured, and their place in the literature is presented in Table 1.

Table 2 displays the descriptive statistics. Although the students in our sample might not be a representative cross-section of the population, they should represent a sample of potential users of robo-investors as they (1) should be aware of the existence of robo-advisors; (2) should show relatively good financial capability (see Oehler et al. 2018b, see also Hohenberger et al. 2019 for the importance of perceived investment capabilities); (3) likely do not have a well-established and trust-based relationship with a financial advisor; and (4) are less likely to be algorithm averse (Rossi and Utkus 2020a).

Participants received the questionnaire in the German language; see the Internet Appendix for an English translation of the questionnaire.

\subsection{Empirical Analysis}

We first provide univariate tests of equality (t-tests) to analyze the differences in the characteristics and asset allocation of participants who are willing to use the robo-advisor (robo-users) versus those who are not (robo-avoiders). 
Table 2 Summary Statistics

\begin{tabular}{|c|c|c|c|c|c|}
\hline & Mean & Median & SD & Min & $\operatorname{Max}$ \\
\hline \multicolumn{6}{|l|}{ Panel A: Participants' characteristics } \\
\hline$C R T$ & 3.65 & 4.00 & 1.63 & .00 & 6.00 \\
\hline GENDER & .51 & & & .00 & 1.00 \\
\hline LOTTERY_RISKY & 453.52 & 5.00 & 863.29 & .00 & $4,000.00$ \\
\hline LOTTERY_UNCERTAIN & 362.45 & 2.00 & 754.38 & .00 & $3,250.00$ \\
\hline RISK_ATTITUDE & 4.60 & 4.00 & 2.11 & .00 & 10.00 \\
\hline \multicolumn{6}{|l|}{ PANAS } \\
\hline NEGAFFECT & 1.60 & 1.00 & .89 & 1.00 & 5.00 \\
\hline POSAFFECT & 3.06 & 3.00 & .96 & 1.00 & 5.00 \\
\hline \multicolumn{6}{|l|}{ KNOWLEDGE } \\
\hline KNOWLEDGE_STATISTICS & 4.25 & 4.00 & .94 & 1.00 & 6.00 \\
\hline SCORE_FIN_KNOW & 3.70 & 4.00 & 2.46 & .00 & 10.00 \\
\hline \multicolumn{6}{|l|}{ LOCUS_OF_CONTROL } \\
\hline EXTLOCUS & 2.18 & 2.00 & .66 & 1.00 & 4.00 \\
\hline INTLOCUS & 4.20 & 4.00 & .56 & 2.50 & 5.00 \\
\hline \multicolumn{6}{|l|}{ PERSONALITY } \\
\hline AGREEABLENESS & 3.06 & 3.00 & .83 & 1.00 & 5.00 \\
\hline CONSCIENTIOUSNESS & 3.55 & 3.50 & .74 & 1.00 & 5.00 \\
\hline EXTRAVERT & 3.37 & 3.50 & .94 & 1.00 & 5.00 \\
\hline NEUROTICISM & 2.89 & 3.00 & .96 & 1.00 & 5.00 \\
\hline OPENNESS & 3.30 & 3.50 & 1.03 & 1.00 & 5.00 \\
\hline \multicolumn{6}{|l|}{ LIFE_ORIENTATION } \\
\hline LIFE_ORIENTATION_OPTIMISM & 11.13 & 11.00 & 2.28 & 5.00 & 15.00 \\
\hline LIFE_ORIENTATION_PESSIMISM & 7.37 & 7.00 & 2.17 & 3.00 & 15.00 \\
\hline \multicolumn{6}{|l|}{ FINANCIAL_ADVICE } \\
\hline PERSONAL_FINANCIAL_ADVICE & .26 & & & .00 & 1.00 \\
\hline ROBO_FINANCIAL_ADVICE & .02 & & & .00 & 1.00 \\
\hline \multicolumn{6}{|l|}{ EXPERIENCE_STOCKS } \\
\hline EXPERIENCE_STOCK_MARKET & .19 & & & .00 & 1.00 \\
\hline EXPERIENCE_STOCK_MARKET_SATISFIED & 3.86 & 4.00 & .99 & 1.00 & 5.00 \\
\hline \multicolumn{6}{|l|}{ TRUST } \\
\hline CONFIDENCE & 2.07 & 1.00 & 1.38 & 1.00 & 5.00 \\
\hline TRUST_AUTHORITIES_GENERAL & 2.67 & 3.00 & .90 & 1.00 & 4.00 \\
\hline TRUST_AUTHORITIES_FINANCIAL & 3.54 & 3.00 & 1.32 & 1.00 & 4.00 \\
\hline TRUST_COURTS & 3.08 & 3.00 & .95 & 1.00 & 4.00 \\
\hline TRUST_FINANCIAL_SERVICE_PROVIDERS & 2.51 & 2.00 & .89 & 1.00 & 4.00 \\
\hline TRUST_FRIENDS_GENERAL & 3.71 & 4.00 & .51 & 1.00 & 4.00 \\
\hline TRUST_FRIENDS_MONETORY & 3.12 & 3.00 & .97 & 1.00 & 5.00 \\
\hline TRUST_FRIENDS_NON-MONETORY & 3.24 & 3.00 & .97 & 1.00 & 5.00 \\
\hline TRUST_OTHER_PEOPLE & .27 & & & .00 & 1.00 \\
\hline TRUST_POLICE & 2.89 & 3.00 & .74 & 1.00 & 4.00 \\
\hline TRUST_PRESS & 2.48 & 2.00 & .96 & 1.00 & 4.00 \\
\hline TRUST_STIFTUNG_WARENTEST & 2.74 & 3.00 & .98 & 1.00 & 4.00 \\
\hline
\end{tabular}


Table 2 (continued)

\begin{tabular}{llllll}
\hline & Mean & Median & SD & Min & Max \\
\hline $\begin{array}{l}\text { Panel B: Investment Decision } \\
\text { AMOUNT_INVESTED_IN_- }\end{array}$ & 591.36 & 600 & 355.60 & 0 & 1,000 \\
STOCKS_BONDS_FUNDS & .53 & & & 0 & 1 \\
INVEST_WITH_ROBO & 314.65 & 250 & 299.82 & .00 & 1,000 \\
INVEST_WITHOUT_ROBO_AMOUNT & & & & & \\
\hline
\end{tabular}

Then, we run a logit regression to analyze the determinants of the decision to use a roboadvisor with the following model:

$$
\begin{aligned}
& I N V E S T \_W I T H \_R O B O_{i}=\beta_{0}+\beta_{1} G E N D E R_{i}+\beta_{2} R I S K \_A T T I T U D E_{i} \\
& +\beta_{3} L N\left(\text { LOTTERY_RISKY }_{i}\right)+\beta_{4} L N\left(\text { LOTTERY_UNCERTAIN }_{i}\right) \\
& +\beta_{5} \text { CRT }_{i}+\gamma_{1} \text { PANAS }_{i}+\gamma_{2} \text { KNOWLEDGE }_{i} \\
& +\gamma_{3} \text { LOCUS_OF_CONTROL } L_{i}+\gamma_{4} \text { PERSONALITY }_{i}+ \\
& \gamma_{5} \text { LIFE_ORIENTATION }{ }_{i}+\gamma_{6} \text { FINANCIAL_ADVICE }{ }_{i} \\
& +\gamma_{7} \text { EXPERIENCE_STOCKS } S_{i}+\gamma_{8} \text { TRUST }_{i}+\varepsilon_{1, i}
\end{aligned}
$$

The dependent variable equals one if the participant is willing to use the robo-advisor and zero otherwise. Table 1 has the descriptions of the explanatory variables and vectors of variables $^{6}$ that enter the regression analysis.

Robo-users do not have to use the robo-advisor exclusively but are also allowed to invest any remaining money on their own. Therefore, we also perform a series of t-tests between two subsamples within the group of robo-users. Specifically, we analyze the differences in asset allocations and individual characteristics between participants who only used the robo-advisor (robo-only-investors) versus participants who used the robo-advisor for some of the money while investing the remaining amount on their own (robo-plus-investors). Furthermore, we perform a multinomial logistic regression using the following model:

$$
\begin{aligned}
R O B O \_U S A G E_{i} & =\beta_{0}+\beta_{1} G E N D E R_{i}+\beta_{2} R I S K_{-} A T T I T U D E_{i} \\
& +\beta_{3} L O T T E R Y \_R I S K Y_{i} \\
& +\beta_{4} L O T T E R Y \_U N C E R T A I N_{i}+\beta_{5} C R T_{i} \\
& +\gamma_{1} \text { PANAS }_{i}+\gamma_{2} \text { KNOWLEDGE } \\
& +\gamma_{3} \text { LOCUS_OF_CONTROL }{ }_{i} \\
& +\gamma_{4} \text { PERSONALITY }{ }_{i}+\gamma_{5} \text { LIFE_ORIENTATION } \\
& +\gamma_{6} \text { FINANCIAL_ADVICE } \\
& +\gamma_{7} \text { EXPERIENCE_STOCKS }{ }_{i}+\gamma_{8} \text { TRUST }_{i}+\varepsilon_{1, i}
\end{aligned}
$$

ROBO_USAGE $E_{i}$ covers three outcomes: no use of the robo-advisor, that is, robo-avoiders; only use the robo-advisor for investing, that is, robo-only-investors; and to use the robo-advisor for some of the money in combination with investing the remaining amount on their own, that is, robo-plus-investors. The first outcome serves as the reference point in

${ }^{6}$ Vectors of variables and vectors of the corresponding coefficients are in bold print. 
Table 3 Characteristics of participants willing to use the robo-advisor (robo-users) in comparison to characteristics of remaining participants (robo-avoiders). We report the mean values (standard deviations in parentheses) of the characteristics of participants willing to use the robo-advisor (robo-users) in comparison to the characteristics of participants not willing to use the robo-advisor (robo-avoiders). In addition, we provide the p-values of t-tests of equality of mean values of the participants' characteristics

\begin{tabular}{|c|c|c|c|}
\hline & $\begin{array}{l}\text { robo-users } \\
\text { (1) }\end{array}$ & $\begin{array}{l}\text { robo-avoiders } \\
\text { (2) }\end{array}$ & $\begin{array}{l}p \text {-value } \\
\text { (3) }\end{array}$ \\
\hline GENDER & $\begin{array}{l}.50 \\
(.50)\end{array}$ & $\begin{array}{l}.52 \\
(.50)\end{array}$ & .777 \\
\hline RISK_ATTITUDE & $\begin{array}{l}4.89 \\
(1.98)\end{array}$ & $\begin{array}{l}4.28 \\
(2.20)\end{array}$ & .030 \\
\hline LOTTERY_RISKY & $\begin{array}{l}394.46 \\
(796.65)\end{array}$ & $\begin{array}{l}519.70 \\
(931.63)\end{array}$ & .274 \\
\hline LOTTERY_UNCERTAIN & $\begin{array}{l}318.05 \\
(670.26)\end{array}$ & $\begin{array}{l}412.18 \\
(839.10)\end{array}$ & .347 \\
\hline POSAFFECT & $\begin{array}{l}3.17 \\
(.91)\end{array}$ & $\begin{array}{l}2.95 \\
(1.01)\end{array}$ & .073 \\
\hline NEGAFFECT & $\begin{array}{l}1.52 \\
(.79)\end{array}$ & $\begin{array}{l}1.68 \\
(.98)\end{array}$ & .188 \\
\hline$C R T$ & $\begin{array}{l}3.67 \\
(1.55)\end{array}$ & $\begin{array}{l}3.62 \\
(1.74)\end{array}$ & .823 \\
\hline SCORE_FIN_KNOW & $\begin{array}{l}3.81 \\
(2.65)\end{array}$ & $\begin{array}{l}3.58 \\
(2.22)\end{array}$ & .472 \\
\hline KNOWLEDGE_STATISTICS & $\begin{array}{l}4.33 \\
(.98)\end{array}$ & $\begin{array}{l}4.17 \\
(.88)\end{array}$ & .188 \\
\hline INTLOCUS & $\begin{array}{l}4.19 \\
(.57)\end{array}$ & $\begin{array}{l}4.20 \\
(.56)\end{array}$ & .901 \\
\hline EXTLOCUS & $\begin{array}{l}2.14 \\
(.66)\end{array}$ & $\begin{array}{l}2.22 \\
(.67)\end{array}$ & .418 \\
\hline AGREEABLENESS & $\begin{array}{l}3.07 \\
(.80)\end{array}$ & $\begin{array}{l}3.06 \\
(.86)\end{array}$ & .949 \\
\hline CONSCIENTIOUSNESS & $\begin{array}{l}3.56 \\
(.72)\end{array}$ & $\begin{array}{l}3.54 \\
(.76)\end{array}$ & .832 \\
\hline EXTRAVERT & $\begin{array}{l}3.49 \\
(.88)\end{array}$ & $\begin{array}{l}3.23 \\
(1.01)\end{array}$ & .035 \\
\hline NEUROTICISM & $\begin{array}{l}2.88 \\
(.96)\end{array}$ & $\begin{array}{l}2.91 \\
(.97)\end{array}$ & .825 \\
\hline OPENNESS & $\begin{array}{l}3.31 \\
(1.00)\end{array}$ & $\begin{array}{l}3.30 \\
(1.06)\end{array}$ & .946 \\
\hline LIFE_ORIENTATION_OPTIMISM & $\begin{array}{l}11.44 \\
(2.24)\end{array}$ & $\begin{array}{l}10.79 \\
(2.30)\end{array}$ & .030 \\
\hline LIFE_ORIENTATION_PESSIMISM & $\begin{array}{l}7.10 \\
(2.10)\end{array}$ & $\begin{array}{l}7.67 \\
(2.22)\end{array}$ & .048 \\
\hline PERSONAL_FINANCIAL_ADVICE & $\begin{array}{l}.23 \\
(.42)\end{array}$ & $\begin{array}{l}.29 \\
(.45)\end{array}$ & .339 \\
\hline ROBO_FINANCIAL_ADVICE & $\begin{array}{l}.02 \\
(.16)\end{array}$ & $\begin{array}{l}.02 \\
(.13)\end{array}$ & .739 \\
\hline EXPERIENCE_STOCK_MARKET & $\begin{array}{l}.18 \\
(.39)\end{array}$ & $\begin{array}{l}.19 \\
(.40)\end{array}$ & .811 \\
\hline EXPERIENCE_STOCK_MARKET_SATISFIED & $\begin{array}{l}4.05 \\
(.79)\end{array}$ & $\begin{array}{l}3.67 \\
(1.15)\end{array}$ & .911 \\
\hline
\end{tabular}


Table 3 (continued)

\begin{tabular}{|c|c|c|c|}
\hline & $\begin{array}{l}\text { robo-users } \\
\text { (1) }\end{array}$ & $\begin{array}{l}\text { robo-avoiders } \\
\text { (2) }\end{array}$ & $\begin{array}{l}p \text {-value } \\
\text { (3) }\end{array}$ \\
\hline CONFIDENCE & $\begin{array}{l}2.14 \\
(1.44)\end{array}$ & $\begin{array}{l}2.00 \\
(1.30)\end{array}$ & .444 \\
\hline TRUST_AUTHORITIES_GENERAL & $\begin{array}{l}2.59 \\
(.84)\end{array}$ & $\begin{array}{l}2.75 \\
(.95)\end{array}$ & .171 \\
\hline TRUST_AUTHORITIES_FINANCIAL & $\begin{array}{l}3.45 \\
(1.26)\end{array}$ & $\begin{array}{l}3.65 \\
(1.38)\end{array}$ & .240 \\
\hline TRUST_COURTS & $\begin{array}{l}3.04 \\
(.083)\end{array}$ & $\begin{array}{l}3.12 \\
(1.08)\end{array}$ & .534 \\
\hline TRUST_FINANCIAL_SERVICE_PROVIDERS & $\begin{array}{l}2.55 \\
(.86)\end{array}$ & $\begin{array}{l}2.46 \\
(.93)\end{array}$ & .444 \\
\hline TRUST_FRIENDS_GENERAL & $\begin{array}{l}3.74 \\
(.53)\end{array}$ & $\begin{array}{l}3.69 \\
(.48)\end{array}$ & .159 \\
\hline TRUST_FRIENDS_MONETORY & $\begin{array}{l}3.14 \\
(.96)\end{array}$ & $\begin{array}{l}3.10 \\
(.97)\end{array}$ & .764 \\
\hline TRUST_FRIENDS_NON-MONETORY & $\begin{array}{l}3.21 \\
(.97)\end{array}$ & $\begin{array}{l}3.28 \\
(.96)\end{array}$ & .627 \\
\hline TRUST_OTHER_PEOPLE & $\begin{array}{l}.28 \\
(.45)\end{array}$ & $\begin{array}{l}.26 \\
(.44)\end{array}$ & .771 \\
\hline TRUST_POLICE & $\begin{array}{l}2.93 \\
(.74)\end{array}$ & $\begin{array}{l}2.84 \\
(.75)\end{array}$ & .403 \\
\hline TRUST_PRESS & $\begin{array}{l}2.54 \\
(.90)\end{array}$ & $\begin{array}{l}2.41 \\
(1.02)\end{array}$ & .312 \\
\hline TRUST_STIFTUNG_WARENTEST & $\begin{array}{l}2.73 \\
(.87)\end{array}$ & $\begin{array}{l}2.75 \\
(1.10)\end{array}$ & .861 \\
\hline $\mathrm{N}$ & 122 & 109 & \\
\hline
\end{tabular}

our analysis. Using Eq. (2) with $S O L E L Y \_U S I N G \_R O B O_{i}$ as the dependent variable, we also apply a logit regression analysis to the subsample of robo-users to discover the characteristics that drive the decision to use the robo-advisor solely or in combination with their own investments in stocks and bonds.

To be able to uncover the determinants of the amount that participants would invest with the robo-advisor and the stock ratio they would choose for this investment, we need to account for the fact that not all participants use the robo-advisor. Therefore, we applied two approaches. First, we used a Tobit regression approach on the full sample. Second, we used an OLS regression to approximate a truncated regression only on the subsample of robo-users, that is, only including responses from participants that actually invest an amount using the robo-advisor that is different from zero. ${ }^{7}$ The underlying model is as follows:

For the dependent variable, ROBO_INVESTMENT , we use either the amount of money that participant $i$ is willing to invest with the robo-advisor, INVEST_WITH_ROBO_ $A M O U N T_{i}$, or the stock ratio that he or she chooses for the investment with the robo-advisor, INVEST_WITH_ROBO_STOCK_RATIO ${ }_{i}$.

7 See Breen (1996) on truncated regressions. 


$$
\begin{aligned}
& \text { ROBO_INVESTMENT }{ }_{i}=\beta_{0}+\beta_{1} \text { GENDER }_{i}+\beta_{2} R I S K_{-} \text {ATTITUDE } E_{i} \\
& +\beta_{3} L N\left(\text { LOTTERY_RISKY } Y_{i}\right) \\
& +\beta_{4} L N\left(L O T T E R Y \_U N C E R T A I N_{i}\right) \\
& +\beta_{5} C R T_{i} \\
& +\gamma_{1} \text { PANAS }_{i} \\
& +\gamma_{2} \text { KNOWLEDGE } \\
& +\gamma_{3} \text { LOCUS_OF_CONTROL } \\
& +\gamma_{4} \text { PERSONALITY } \\
& +\gamma_{5} \text { LIFE_ORIENTATION } \\
& +\gamma_{6} \text { FINANCIAL_ADVICE } \\
& +\gamma_{7} \text { EXPERIENCE_STOCKS } \\
& +\gamma_{8} \text { TRUST }_{i}+\beta_{6} \text { SOLELY_USING_ROBO }{ }_{i}+\varepsilon_{1, i}
\end{aligned}
$$

\section{Results}

\subsection{Characteristics and Asset Allocation of Robo-users vs. Robo-avoiders}

We report the mean values of the characteristics of the participants who are willing to invest with the robo-advisor (robo-users) and of the participants who are not willing to invest with the robo-advisor (robo-avoiders) in Table 3. Of the participants, 53\% are willing to invest on average 524 Euros (out of 1,000 Euros) with the robo-advisor. This usage shows that our sample contains a high percentage of participants who do not preclude using a robo-advisor a priori. The percentage supports our approach of using young adults as participants. The results of the t-tests show that robo-users show a significantly higher willingness to take financial risks (4.89 vs. 4.28), a higher degree of extraversion (3.49 vs. 3.23 ), more optimism (11.44 vs. 10.79$)$, and less pessimism (7.10 vs. 7.67$)$ than robo-avoiders. This difference is statistically significant at the $5 \%$ level for each of these characteristics.

The results of the logit regression in Table 4 show that participants with a higher willingness to take financial risks, that is, a lower degree of risk aversion, are more likely to use a robo-advisor. The corresponding coefficient is 0.26 , and the influence is statistically significant at the $1 \%$ level. This finding is in line with the t-test results. In contrast to the t-tests, however, the results of the regression analysis do not show a significant influence from the participants' degree of extraversion, optimism, and pessimism. The latter effect is not driven by multicollinearity between risk attitude, extraversion, optimism, and pessimism. The untabulated results of a correlation analysis indicate no significant correlation between the risk attitude and the remaining three factors (however, the latter ones are correlated with each other with statistical significance at the $1 \%$ level). Moreover, with statistical significance at the $1 \%$ level, the coefficient of -1.03 for INTLOCUS indicates higher chances that participants with a lower internal locus of control use a robo-advisor, that is, that people who attribute outcomes of events (e.g., investment outcomes) less to their own control are more likely to transfer the portfolio management to the robo-advisor. The results of the logit regression indicate a good model fit as $68.4 \%$ of the estimates are 
Table 4 Participants' characteristics as determinants for use of robo-advisor. We provide regression coefficients, Cragg \& Uhler's Pseudo- ${ }^{2}$, and the percentage of correct estimates for the logit regression analysis using Eq. (1) with the decision to invest in the robo-advisor as the dependent variable. The table has the results for the full regression model

\begin{tabular}{ll}
\hline & $I^{N V E S T}-$ \\
& WITH_ \\
& ROBO \\
& $(1)$ \\
\hline GENDER & .14 \\
RISK_ATTITUDE & $.26^{* *}$ \\
LN(LOTTERY_RISKY) & -.12 \\
LN(LOTTERY_UNCERTAIN) & .14 \\
CRT & .05 \\
PANAS & $\mathrm{ns}$ \\
KNOWLEDGE & $\mathrm{ns}$ \\
INTLOCUS & $-1.03^{* * *}$ \\
EXTLOCUS & -.02 \\
PERSONALITY & $\mathrm{ns}$ \\
LIFE_ORIENTATION & $\mathrm{ns}$ \\
FINANCIAL_ADVICE & $\mathrm{ns}$ \\
EXPERIENCE_STOCKS & $\mathrm{ns}$ \\
TRUST & $\mathrm{ns}$ \\
$\beta_{0}$ & .71 \\
Cragg \& Uhler's Pseudo-R ${ }^{2}$ & .21 \\
Percentage of correct estimates & 68.4 \\
\hline
\end{tabular}

The symbols $* * * *, * * *, * *$, and $*$ denote significance at the $1 \%$ o, 5\%o, $1 \%$, and $5 \%$ levels, respectively; ns denotes not significant, i.e., p-values $\geq 0.05$

correct. A post hoc test for statistical power shows high power for the regression and that the results are not driven by multicollinearity. ${ }^{8}$

The asset allocations of robo-users and of robo-avoiders as presented in Table 5 again show robo-avoiders' lower willingness to take financial risk. All differences in the asset allocations are statistically significant at the $1 \%$ o level. Robo-users on average invest 773 Euros in stocks and bonds (including the 524 Euros they invest using the robo-advisor). Robo-avoiders only invest 387 Euros in stocks and bonds. Since roboavoiders still invest some money in stocks and bonds, not using the robo-advisor may indicate an active choice against the robo-advisor and not a choice against risky investments per se.

As an interim conclusion, we can state that participants with a lower degree of risk aversion are more likely to use a robo-advisor. Our findings so far indicate that investors with a higher willingness to take financial risk have the opportunity to benefit from delegating

\footnotetext{
${ }^{8}$ The only variables with a variance inflation factor (VIF) higher than 10 are the pairs LN(LOTTERY RISKY)/LN(LOTTERY_UNCERTAIN) and EXPERIENCE_STOCK_MARKET/EXPERIENCE_STOCK_ MARKET_SATISFIED which is not surprising given that the latter variable is an interacted variable that includes the previous one. The VIFs for the regression models that exclude LN(LOTTERY_RISKY) and EXPERIENCE_STOCK_MARKET do not exceed 2.2. The corresponding regression coefficients are almost identical to the ones reported in Table 4. In particular, the regression coefficients for the two significant characteristics RISK_ATTITUDE and INTLOCUS do not change considerably (.26 vs. .25 and -1.03 vs. -1.03), see Appendix, Table 9 for the detailed results.
} 
Table 5 Asset allocation of investors willing to use a robo-advisor (robo-users) and that of the remaining investors (robo-avoiders). We report the mean values (standard deviations in parentheses) of the amount of money that participants invest in stocks and bonds that is subdivided in the amount that participants invest with and without the robo-advisor for participants willing to use the robo-advisor (robo-users) in comparison to the participants not willing to use the robo-advisor (robo-avoiders). In addition, we provide the p-values of t-tests of equality of mean values

\begin{tabular}{llll}
\hline & $\begin{array}{l}\text { robo-users } \\
(1)\end{array}$ & $\begin{array}{l}\text { robo-avoiders } \\
(2)\end{array}$ & $\begin{array}{l}\text { p-value } \\
(3)\end{array}$ \\
\hline AMOUNT_INVESTED_IN_- & 773.61 & 387.39 & .000 \\
STOCKS_BONDS_FUNDS & $(.242 .57)$ & $(351.95)$ & \\
INVEST_WITH_ROBO_AMOUNT & 523.93 & & .000 \\
INVEST_WITHOUT_ROBO_AMOUNT & $(242.64)$ & 387.39 & $(351.95)$ \\
$\mathrm{N}$ & 249.67 & 109 & \\
\hline
\end{tabular}

Table 6 Asset allocation of investors who only use a robo-advisor (robo-only-investors) and of investors who combine the use of the robo-advisor with their own investments (robo-plus-investors). We report the mean values (standard deviations in parentheses) of the amount of money that participants invest in stocks and bonds and the stock ratio that participants choose with their asset allocation. We subdivide the sample into participants who invest solely with the robo-advisor (robo-only-investors) and participants who invest the robo-advisor in combination with other investments (robo-plus-investors). In addition, we provide the p-values of t-tests of equality of mean values

\begin{tabular}{|c|c|c|c|}
\hline & $\begin{array}{l}\text { robo-only-investors } \\
\text { (1) }\end{array}$ & $\begin{array}{l}\text { robo-plus-investors } \\
\text { (2) }\end{array}$ & $\begin{array}{l}p \text {-value } \\
\text { (3) }\end{array}$ \\
\hline $\begin{array}{l}\text { AMOUNT_INVESTED_IN_} \\
\text { STOCKS_BONDS_FUNDS }\end{array}$ & $\begin{array}{l}631.75 \\
(303.47)\end{array}$ & $\begin{array}{l}842.80 \\
(169.63)\end{array}$ & .000 \\
\hline INVEST_WITH_ROBO_AMOUNT & $\begin{array}{l}631.75 \\
(303.47)\end{array}$ & $\begin{array}{l}471.34 \\
(187.25)\end{array}$ & .000 \\
\hline INVEST_WITH_ROBO_STOCK_RATIO & $\begin{array}{l}51.03 \\
(21.00)\end{array}$ & $\begin{array}{l}63.29 \\
(19.79)\end{array}$ & .002 \\
\hline $\begin{array}{l}\text { INVEST_WITHOUT_ROBO_AMOUNT } \\
\text { BOND INDEX FUNDS }\end{array}$ & & $\begin{array}{l}25.12 \\
(62.89)\end{array}$ & \\
\hline $\begin{array}{l}\text { INVEST_WITHOUT_ROBO_AMOUNT } \\
\text { BOND MUTUAL FUNDS }\end{array}$ & & $\begin{array}{l}19.94 \\
(51.77)\end{array}$ & \\
\hline $\begin{array}{l}\text { INVEST_WITHOUT_ROBO_AMOUNT } \\
\text { INDIVIDUALBONDS }\end{array}$ & & $\begin{array}{l}32.93 \\
(71.24)\end{array}$ & \\
\hline $\begin{array}{l}\text { INVEST_WITHOUT_ROBO_AMOUNT } \\
\text { STOCK INDEX FUNDS }\end{array}$ & & $\begin{array}{l}97.07 \\
(147.19)\end{array}$ & \\
\hline $\begin{array}{l}\text { INVEST_WITHOUT_ROBO_AMOUNT } \\
\text { STOCK MUTUAL FUNDS }\end{array}$ & & $\begin{array}{l}60.61 \\
(111.46)\end{array}$ & \\
\hline $\begin{array}{l}\text { INVEST_WITHOUT_ROBO_AMOUNT_ } \\
\text { INDIVIDUALSTOCKS }\end{array}$ & & $\begin{array}{l}87.38 \\
(127.98)\end{array}$ & \\
\hline INVEST_WITHOUT_ROBO_STOCK_RATIO & & $\begin{array}{l}74.36 \\
(32.72)\end{array}$ & \\
\hline $\begin{array}{l}\text { INVEST_WITHOUT_ROBO_AMOUNT_ } \\
\text { BALANCED MUTUAL FUNDS }\end{array}$ & & $\begin{array}{l}48.41 \\
(125.10)\end{array}$ & \\
\hline $\mathrm{N}$ & 40 & 82 & \\
\hline
\end{tabular}


Table 7 Characteristics of participants who are willing to only use the robo-advisor (robo-only-investors) and of participants who combine the use of the robo-advisor with their own investments (robo-plus-investors). We report the mean values (standard deviations in parentheses) of the characteristics of participants who are willing to only use the robo-advisor (robo-only-investors) in comparison to the characteristics of participants who use the robo-advisor in combination with other investments (robo-plus-investors). In addition, we provide the p-values of t-tests of equality of mean values of the participants' characteristics

\begin{tabular}{|c|c|c|c|}
\hline & $\begin{array}{l}\text { robo-only-investors } \\
\text { (1) }\end{array}$ & $\begin{array}{l}\text { robo-plus-investors } \\
\text { (2) }\end{array}$ & $\begin{array}{l}p \text {-value } \\
\text { (3) }\end{array}$ \\
\hline GENDER & $\begin{array}{l}.49 \\
(.51)\end{array}$ & $\begin{array}{l}.51 \\
(.50)\end{array}$ & .799 \\
\hline RISK_ATTITUDE & $\begin{array}{l}4.58 \\
(1.97)\end{array}$ & $\begin{array}{l}5.04 \\
(1.98)\end{array}$ & .229 \\
\hline LOTTERY_RISKY & $\begin{array}{l}278.83 \\
(631.88)\end{array}$ & $\begin{array}{l}449.45 \\
(862.22)\end{array}$ & .222 \\
\hline LOTTERY_UNCERTAIN & $\begin{array}{l}275.19 \\
(633.34)\end{array}$ & $\begin{array}{l}338.44 \\
(689.98)\end{array}$ & .630 \\
\hline POSAFFECT & $\begin{array}{l}2.95 \\
(.93)\end{array}$ & $\begin{array}{l}3.28 \\
(.88)\end{array}$ & .058 \\
\hline NEGAFFECT & $\begin{array}{l}1.35 \\
(.62)\end{array}$ & $\begin{array}{l}1.61 \\
(.86)\end{array}$ & .060 \\
\hline$C R T$ & $\begin{array}{l}3.60 \\
(1.78)\end{array}$ & $\begin{array}{l}3.71 \\
(1.43)\end{array}$ & .740 \\
\hline SCORE_FIN_KNOW & $\begin{array}{l}3.03 \\
(1.76)\end{array}$ & $\begin{array}{l}4.20 \\
(2.93)\end{array}$ & .007 \\
\hline KNOWLEDGE_STATISTICS & $\begin{array}{l}4.58 \\
(.78)\end{array}$ & $\begin{array}{l}4.21 \\
(1.05)\end{array}$ & .032 \\
\hline INTLOCUS & $\begin{array}{l}4.23 \\
(.53)\end{array}$ & $\begin{array}{l}4.18 \\
(.59)\end{array}$ & .663 \\
\hline EXTLOCUS & $\begin{array}{l}2.09 \\
(.72)\end{array}$ & $\begin{array}{l}2.17 \\
(.63)\end{array}$ & .503 \\
\hline AGREEABLENESS & $\begin{array}{l}3.10 \\
(.80)\end{array}$ & $\begin{array}{l}3.05 \\
(.81)\end{array}$ & .429 \\
\hline CONSCIENTIOUSNESS & $\begin{array}{l}3.50 \\
(.68)\end{array}$ & $\begin{array}{l}3.59 \\
(.74)\end{array}$ & .631 \\
\hline EXTRAVERT & $\begin{array}{l}3.44 \\
(.88)\end{array}$ & $\begin{array}{l}3.52 \\
(.87)\end{array}$ & .527 \\
\hline NEUROTICISM & $\begin{array}{l}2.78 \\
(1.08)\end{array}$ & $\begin{array}{l}2.93 \\
(.89)\end{array}$ & .736 \\
\hline OPENNESS & $\begin{array}{l}3.23 \\
(1.10)\end{array}$ & $\begin{array}{l}3.35 \\
(.95)\end{array}$ & .544 \\
\hline LIFE_ORIENTATION_OPTIMISM & $\begin{array}{l}11.55 \\
(2.26)\end{array}$ & $\begin{array}{l}11.39 \\
(2.24)\end{array}$ & .713 \\
\hline LIFE_ORIENTATION_PESSIMISM & $\begin{array}{l}7.38 \\
(2.39)\end{array}$ & $\begin{array}{l}6.96 \\
(1.95)\end{array}$ & .312 \\
\hline PERSONAL_FINANCIAL_ADVICE & $\begin{array}{l}.15 \\
(.36)\end{array}$ & $\begin{array}{l}.27 \\
(.45)\end{array}$ & .112 \\
\hline ROBO_FINANCIAL_ADVICE & $\begin{array}{l}.00 \\
(.00)\end{array}$ & $\begin{array}{l}.04 \\
(.19)\end{array}$ & .083 \\
\hline EXPERIENCE_STOCK_MARKET & $\begin{array}{l}.05 \\
(.22)\end{array}$ & $\begin{array}{l}.24 \\
(.43)\end{array}$ & .001 \\
\hline EXPERIENCE_STOCK_MARKET_SATISFIED & $\begin{array}{l}4.00 \\
(.00)\end{array}$ & $\begin{array}{l}4.05 \\
(.83)\end{array}$ & .934 \\
\hline
\end{tabular}


Table 7 (continued)

\begin{tabular}{|c|c|c|c|}
\hline & $\begin{array}{l}\text { robo-only-investors } \\
\text { (1) }\end{array}$ & $\begin{array}{l}\text { robo-plus-investors } \\
\text { (2) }\end{array}$ & $\begin{array}{l}p \text {-value } \\
\text { (3) }\end{array}$ \\
\hline CONFIDENCE & $\begin{array}{l}1.88 \\
(1.28)\end{array}$ & $\begin{array}{l}2.27 \\
(1.50)\end{array}$ & .137 \\
\hline TRUST_AUTHORITIES_GENERAL & $\begin{array}{l}2.73 \\
(.91)\end{array}$ & $\begin{array}{l}2.52 \\
(.80)\end{array}$ & .238 \\
\hline TRUST_AUTHORITIES_FINANCIAL & $\begin{array}{l}3.45 \\
(1.30)\end{array}$ & $\begin{array}{l}3.44 \\
(1.25)\end{array}$ & .982 \\
\hline TRUST_COURTS & $\begin{array}{l}3.13 \\
(.88)\end{array}$ & $\begin{array}{l}3.00 \\
(.80)\end{array}$ & .436 \\
\hline TRUST_FINANCIAL_SERVICE_PROVIDERS & $\begin{array}{l}2.70 \\
(1.11)\end{array}$ & $\begin{array}{l}2.48 \\
(.71)\end{array}$ & .249 \\
\hline TRUST_FRIENDS_GENERAL & $\begin{array}{l}3.73 \\
(.51)\end{array}$ & $\begin{array}{l}3.74 \\
(.54)\end{array}$ & .853 \\
\hline TRUST_FRIENDS_MONETORY & $\begin{array}{l}3.00 \\
(1.15)\end{array}$ & $\begin{array}{l}3.21 \\
(.86)\end{array}$ & .317 \\
\hline TRUST_FRIENDS_NON-MONETORY & $\begin{array}{l}3.33 \\
(1.02)\end{array}$ & $\begin{array}{l}3.16 \\
(.95)\end{array}$ & .377 \\
\hline TRUST_OTHER_PEOPLE & $\begin{array}{l}.26 \\
(.45)\end{array}$ & $\begin{array}{l}.29 \\
(.46)\end{array}$ & .785 \\
\hline TRUST_POLICE & $\begin{array}{l}2.83 \\
(.75)\end{array}$ & $\begin{array}{l}2.98 \\
(.74)\end{array}$ & .293 \\
\hline TRUST_PRESS & $\begin{array}{l}2.38 \\
(.84)\end{array}$ & $\begin{array}{l}2.62 \\
(.92)\end{array}$ & .156 \\
\hline TRUST_STIFTUNG_WARENTEST & $\begin{array}{l}2.70 \\
(.88)\end{array}$ & $\begin{array}{l}2.74 \\
(.87)\end{array}$ & .795 \\
\hline $\mathrm{N}$ & 40 & 82 & \\
\hline
\end{tabular}

investing to a robo-advisor as it provides them with the chance to establish a well-diversified portfolio and to potentially mitigate the negative effect of their own behavioral biases.

\subsection{Univariate Differences Between Robo-only- and Robo-plus-investors}

Table 6 presents the mean amounts of money invested in the different asset classes by robo-only-investors and robo-plus-investors. Among the robo-users, 40 participants (33\%) only invest with the robo-advisor (robo-only-investors) while $82(67 \%)$ of the participants combine investing with the robo-advisor and investing in individual stocks, bonds, and index and mutual funds (robo-plus-investors). The t-tests on the asset allocations of these two groups of participants show that robo-only-investors invest a significantly smaller amount in stocks and bonds than robo-plus-investors (632 vs. 843 Euros). However, the robo-plus-investors invest a significantly lower amount via the robo-advisor (471 Euros). Furthermore, robo-only-investors and robo-plus-investors choose a significantly different stock ratio for their investments with a statistical significance at the $2 \%$ o level. While robo-only-investors allocate $51 \%$ of their investment amount in stocks, robo-plus-investors choose a stock ratio of $63 \%$ for investment with the robo-advisor. For the remaining 
Table 8 Participants' characteristics as determinants for use of robo-advisor (multinomial logistic regression, 'No use of robo-advisor' serves as reference). We provide exponentiated regression coefficients and Cragg \& Uhler's Pseudo- $\mathrm{R}^{2}$ for the multinomial logit regression analysis using Eq. (2) with the type of usage of the robo-advisor as the dependent variable. Not using the robo-advisor at all serves as the reference variable. The table has the results for the full regression model

\begin{tabular}{lll}
\hline & $\begin{array}{l}\text { robo-only-investors } \\
(1)\end{array}$ & $\begin{array}{l}\text { robo-plus-investors } \\
(2)\end{array}$ \\
\hline GENDER & 1.04 & .94 \\
RISK_ATTITUDE & 1.27 & $1.38^{* * *}$ \\
LOTTERY_RISKY & 1.00 & 1.00 \\
LOTTERY_UNCERTAIN & 1.00 & 1.00 \\
CRT & 1.05 & 1.12 \\
AFFECT & $\mathrm{ns}$ & $\mathrm{ns}$ \\
SCORE_FIN_KNOW & .97 & 1.07 \\
KNOWLEDGE_STATISTICS & $2.77^{* * *}$ & 1.21 \\
INTLOCUS & .30 & $.36^{* *}$ \\
EXTLOCUS & .79 & 1.17 \\
PERSONALITY & $\mathrm{ns}$ & $\mathrm{ns}$ \\
LIFE_ORIENTATION_OPTIMISM & $1.45^{*}$ & .93 \\
LIFE_ORIENTATION_PESSIMISM & 1.16 & .79 \\
FINANCIAL_ADVICE & $\mathrm{ns}$ & $\mathrm{ns}$ \\
EXPERIENCE_STOCKS & $\mathrm{ns}$ & $\mathrm{ns}$ \\
TRUST & $\mathrm{ns}$ & $\mathrm{ns}$ \\
$\beta_{0}($ not exponential) & -1.18 & -.63 \\
Cragg \& Uhler's Pseudo-R ${ }^{2}$ & .402 & .402 \\
\hline
\end{tabular}

The symbols $* * * *, * * *, * *$, and $*$ denote significance at the $1 \% \circ, 5 \%, 1 \%$, and $5 \%$ level, respectively; ns denotes not significant, i.e., p-values $\geq 0.05$

investments without the robo-advisor, robo-plus-investors choose an even higher stock ratio of $74 \%$. A paired-sample t-test between the stock ratio of investments with and without the robo-advisor of robo-plus-investors shows a statistically significant difference at the $1 \%$ level.

Besides their asset allocation, robo-only-investors and robo-plus-investors also differ in their characteristics. The mean values of the characteristics of robo-onlyinvestors and robo-plus-investors and the corresponding t-test results are presented in Table 7. Robo-plus-investors have better financial knowledge (4.20 vs. 3.03, significant at the $1 \%$ level) and the greater financial experience $(0.24 \mathrm{vs} .0 .05$, significant at the $1 \%$ level). On the other hand, robo-only-investors have more knowledge of statistics (4.58 vs. 4.21$)$ with statistical significance at the $5 \%$ level. Since studies have shown that statistical knowledge, investment experience, and financial knowledge are positively related to investment performance (see Campbell et al. 2014; Corgnet et al. 2018; Graham et al. (2009), von Gaudecker (2015), Nicolosi et al. 2009, Seru et al. 2010), our results do not indicate that robo-only-investors have better investment skills than robo-plus-investors or vice versa. 


\subsection{Multivariate Results}

We provide the results of multinomial logistic regressions to identify the characteristics that drive the decision to become a robo-only-investor or a robo-plus-investor relative to a robo-avoider in Table 8 . The results show a positive exponentiated coefficient of 2.77 for the effect of statistical knowledge on the likelihood of being a robo-only-investor at the 5\%o level of statistical significance (1.21 and not statistically significant for robo-plus-investors). The positive relationship between the degree of optimism and being a robo-onlyinvestor is weak with an exponentiated coefficient of 1.45 but still significant at the 5\% level ( 0.93 and not statistically significant for robo-plus-investors). Robo-plus-investors, on the other hand, show a higher willingness to take financial risks with an exponentiated coefficient of 1.38 with statistical significance at the $5 \%$ level and a lower internal locus of control with a coefficient of $0.36^{9}$ that is statistically significant at the $1 \%$ level. In contrast, robo-only-investors are not associated with a statistically significant higher willingness to take financial risks (exponentiated coefficient of 1.27) or a lower internal locus of control (exponentiated coefficient of 0.30). The regression analysis has strong statistical power and is not driven by multicollinearity issues.

We perform a further logit regression for the subsample of robo-users with a binary dependent variable that indicates whether participants are robo-only-investors or roboplus-investors. The detailed results are presented in Table 10 of the Appendix. Among the robo-users, the participants with better statistical knowledge and a higher degree of optimism are more likely to only use the robo-advisor. We also find that participants with a higher degree of pessimism are also more likely to be robo-only-investors than robo-plus-investors and that is statistically significant at the $1 \%$ level. However, the test for statistical power shows that the regression only has marginal statistical power and should therefore be treated with caution. Hence, it may only serve as mild support for the results in Tables 7 and 8, which is why the detailed results are only presented in the Appendix.

In the regression analysis that uses model (3), we tried to identify the determinants of the amount that participants invest when using the robo-advisor and the stock ratio that they choose when investing with the robo-advisor. We leave the results untabulated as they only marginally add to our findings. ${ }^{10}$ When only using characteristics as independent variables in Tobit regressions on the full sample, the results support our previous findings regarding the determinants of using a robo-advisor; participants with a higher willingness to take financial risks and a lower internal locus of control invest a higher amount with the robo-advisor and choose a higher stock ratio for their investments. In particular, the coefficients for RISK_ATTITUDE and INTLOCUS in the regression with the invested amount (stock ratio) as the dependent variable are 75 and -326. (7.8 and -29.5). Moreover, participants with a higher positive affect invest a higher amount with the robo-advisor (coefficient of 117). When we add a dummy variable that indicates whether a participant is a robo-only-investor or a robo-plus-investor, the significance of participants' willingness

\footnotetext{
9 Please consider that exponentiated coefficients - reflecting odds ratios - are provided in Table 8; the nonexponentiated coefficient of INTLOCUS is -1.03 .

10 The table is available from the authors upon request.
} 
to take financial risks, internal locus of control, and a positive affect stay stable or even slightly increase while the explanatory power of the model with the invested amount (stock ratio) doubles to a Pseudo $\mathrm{R}^{2}$ of 0.06 (0.06). These findings are in line with those reported in Tables 4 and 8 . However, the significance of these relations fully disappears when only using an OLS to approximate model (3) for the subsample of the 122 robo-users. The only relations left, with statistical significance at the 5\% level and coefficients of -113 and 56, are that participants with a lower internal locus of control and higher positive affect invest a higher amount with the robo-advisor.

Assessing investors' capacity and preferences regarding the risk and return of an investment is crucial for robo-advisors in order to propose a suitable stock ratio. When the dependent variable in the OLS on the subsample of robo-users is the stock ratio chosen for the investment through the robo-advisor, then none of the characteristics has a significant influence. Hence, the characteristics neither directly determine the amount invested with the robo-advisor nor the stock ratio chosen for this investment. This lack of an effect indicates that only using the characteristics is not sufficient to derive the risk-return-preferences and/or the risk and return of the investors regarding the different asset classes. Consequently, it is unlikely that robo-advisors would be able to provide a suitable portfolio proposal when solely using these characteristics at hand.

Overall, we conclude that the participants' characteristics have a significant influence on the decision to (additionally) use a robo-advisor. However, further research is needed to better identify the factors that determine the amount invested with the robo-advisor or the stock ratio chosen for this investment.

\section{Discussion and Conclusions}

Our study focuses on younger adults as a target group for robo-advisors to analyze the influence of a broad range of individual characteristics on young retail investors' decision to use a robo-advisor. Beyond the question of whether or not they use the robo-advisor, we also analyze the effect of the individual characteristics on the amount they are willing to invest with the robo-advisor. We use a questionnaire-based survey among 231 undergraduate business students at a German medium-sized university and a series of tests of equality and regression analyses.

Our findings support the hypothesis that less risk-averse retail investors are more likely to use a robo-advisor. We also find that the characteristics of extraversion, optimism, and pessimism are significant in univariate but not in multivariate analyses. Instead, participants with a lower internal locus of control are more likely to use the robo-advisor. In line with the idea that robo-users are less risk averse, we find that they invest a larger amount in stocks and bonds than robo-avoiders.

Thus, our findings do not provide convincing support for the idea that several widely used personality traits or specific trust components matter. While personality traits and trust affect actual investment decision-making (as shown by, e.g., Guiso et al. 2008; Oehler et al. 2018a), those effects indicate that they do not systematically affect the choice of the robo-advisor. However, the trust might also indicate that our participants do not (yet) transfer it from other contexts as measured in our study to the still relatively new robo-advisors. 
When further analyzing the subsample of robo-users, we find that investors who use the robo-advisor and invest in risky assets on their own have better financial knowledge and more experience. Therefore, these investors might be either overconfident regarding their skills at picking assets or they might actually have better investment skills based on their experience (Seru et al. 2010).

Investors who solely use the robo-advisor for investments in risky assets have better statistical knowledge and are more optimistic. This finding indicates that they might be actively avoiding risky investments other than those with the robo-advisor as they can assess the limited potential for an enhancement in portfolio performance when they are already invested in a diversified portfolio with the robo-advisor (Oehler and Wanger 2020).

Our findings provide implications for researchers and practitioners alike. Researchers should be aware that not only retail investors' risk attitude in the financial domain but also other (sometimes related) personal characteristics such as locus of control, life orientation, and statistical knowledge might significantly influence their decisions on which asset classes to invest in and which investment service provider to use. Since new, particularly purely digital, financial service providers have arisen in recent years, further research should focus on the characteristics that influence the long-term relation between retail investors and these new service providers, including the likelihood of changing them.

In addition, more analysis is necessary to determine the impact of individual characteristics on the amount of money an investor is willing to invest using the robo-advisor and on different types of portfolios beyond a simple stock-bond mix. It might be a promising path to investigate the latent factors that affect investors in the process of investment decision making (see, e.g., Yang 2013). Further research should also focus on other groups of potential users of robo-advisors and on further robo-advisors.

Providers of digital financial advice and portfolio management should consider further developing their business model to cater to the needs of investors with higher degrees of risk aversion. For instance, robo-advisors might wish to additionally offer advice on insurance products and real estate finance that are perceived as less risky by retail investors. 


\section{Appendix}

Table 9 Participant

characteristics as determinants for using the robo-advisor. In column (1) we provide regression coefficients, Cragg \& Uhler's Pseudo- $\mathrm{R}^{2}$, and the percentage of correct estimates for the logit regression analysis using Eq. (1) excluding LN(LOTTERY_RISKY) and EXPERIENCE_STOCK $M A R K E T$ with the decision to invest in the robo-advisor as dependent variable. In column (2) we provide the variance inflation factors (VIFs) for each variable or the highest VIF among the variables combined in one vector

\begin{tabular}{lll}
\hline & INVEST_ & (Highest) VIF \\
& WITH_ROBO & $(2)$ \\
& $(1)$ & \\
\hline GENDER & .19 & 1.7 \\
RISK_ATTITUDE & $.25^{* *}$ & 1.6 \\
LN(LOTTERY_UNCERTAIN) & .03 & 1.2 \\
CRT & .05 & 1.3 \\
AFFECT & $\mathrm{ns}$ & 1.6 \\
KNOWLEDGE & $\mathrm{ns}$ & 1.4 \\
INTLOCUS & $-1.03 * *$ & 1.6 \\
EXTLOCUS & .00 & 1.5 \\
PERSONALITY & $\mathrm{ns}$ & 1.6 \\
LIFE_ORIENTATION & $\mathrm{ns}$ & 2.2 \\
FINANCIAL_ADVICE & $\mathrm{ns}$ & 1.2 \\
EXPERIENCE_STOCK_MAR- & -.17 & 1.4 \\
$\quad$ KET_SATISFIED & & \\
TRUST & $\mathrm{ns}$ & 1.6 \\
$\beta_{0}$ & .74 & \\
Cragg \& Uhler's Pseudo-R ${ }^{2}$ & .20 & \\
Percentage of correct estimates & 67.5 & \\
\hline
\end{tabular}

The symbols $* * * *, * * *, * *$, and $*$ denote significance at the $1 \%$, 5\%o, $1 \%$, and $5 \%$ level, respectively; ns denotes not significant, i.e. p-values $\geq 0.05$ 
Table 10 Participant characteristics as determinants for using the robo-advisor exclusively (conditional on using robo-advisor). We provide regression coefficients, Cragg $\&$ Uhler's Pseudo-R ${ }^{2}$, and the percentage of correct estimates for the logit regression analysis using Eq. (2) with the decision to solely invest in the robo-advisor as dependent variable. The table includes the results for the full regression model

\begin{tabular}{ll}
\hline & SOLELY_ \\
& USING_ \\
& $R O B O$ \\
& $(1)$ \\
\hline GENDER & 1.08 \\
RISK_ATTITUDE & -.20 \\
LN(LOTTERY_RISKY) & -.07 \\
LN(LOTTERY_UNCERTAIN) & .09 \\
CRT & -.12 \\
AFFECT & $\mathrm{ns}$ \\
SCORE_FIN_KNOW & -.22 \\
KNOWLEDGE_STATISTICS & $1.06^{*}$ \\
LOCUS_OF_CONTROL & $\mathrm{ns}$ \\
PERSONALITY & $\mathrm{ns}$ \\
LIFE_ORIENTATION_OPTIMISM & $.75^{* * * *}$ \\
LIFE_ORIENTATION_PESSIMISM & $.73^{* * *}$ \\
FINANCIAL_ADVICE & $\mathrm{ns}$ \\
EXPERIENCE_STOCKS & $\mathrm{ns}$ \\
TRUST & $\mathrm{ns}{ }^{\mathrm{b}}$ \\
$\beta_{0}$ & -1.79 \\
Cragg \& Uhler's Pseudo-R ${ }^{2}$ & .543 \\
Percentage of correct estimates & 81.8 \\
\hline
\end{tabular}

The symbols $* * * *, * * *, * *$, and $*$ denote significance at the $1 \%$ o $5 \%$, $1 \%$, and $5 \%$ level, respectively; ns denotes not significant, i.e. p-values $\geq 0.05$

${ }^{\text {a }}$ We only observe a significant negative effect (coefficient $=-1.364$; $\mathrm{p}$-value $=.039)$ for the variable associated with conscientiousness

b We only observe a significant negative effect (coefficient=-1.201; $\mathrm{p}$-value $=.049)$ for the variable associated with trust in the police and a significant negative effect (coefficient $=-1.605$; $\mathrm{p}$-value $=.006$ ) for the variable associated with trust in the press 


\section{Questionnaire}

Dear Madam or Sir,

We kindly ask you to participate in a study on investment decisions by answering the following questionnaire. Answering the questions will take about 30 minutes; as compensation you will receive 5 Euros.

Please read the following questions carefully and answer them in one go. Answer the questions from your point of view, i.e. how you see it. Each participant needs an individual user ID to be able to collect the compensation. Please fill in the following fields to create your user ID:

First letter of your mother's first name:

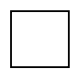

First letter of your father's first name:

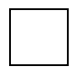

First letter of your birthplace:

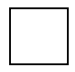

One number between 1 and 9:

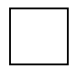

One letter:

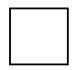

\section{Important!}

Please detach this page carefully and keep the page as a receipt. Your compensation can only be paid out in return for the receipt! Enter your user ID in the fields on the next page. The compensation will be paid out in December 2019.

Your information remains completely anonymous and will be destroyed after the analysis.

\section{Thank you for your support and your cooperation!}


A) Your user ID from the previous page (from top to bottom):

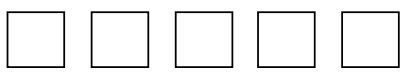

B) Your age:

C) Your gender: $\square$ female $\square$ male

D) Your highest educational degree:

- University of applied science entrance qualification (Fachhochschulreife)

General university entrance qualification (allgemeine Hochschulreife, Abitur)

Finished studies (if yes, which degree:

$\square$ Other \&

E) Current study semester:

Study program:

F) Have you already gathered work experience (also vocational training)?

$\square$ No $\square$ Yes

If yes, in which job / in which vocational training?

G) Have you already gained own experience in the stock market?

$\square$ No $\square$ Yes

If yes:

How many transactions have you done so far?

Would you say that your recent stock market transactions had satisfactory results?

\begin{tabular}{|c|c|c|c|c|}
\hline no, not at all & not really & neither nor & yes, somewhat & yes, completely \\
\hline 0 & $\circ$ & 0 & 0 & 0 \\
\hline
\end{tabular}

H) Please name 5 companies that are currently listed in the DAX.
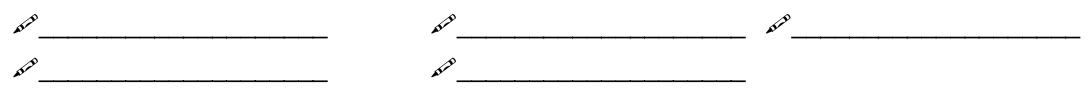

I) Have you consulted a personal financial advisor (including via phone or internet) at a bank or savings bank or a financial advisor on fee basis during the last two years?

\begin{tabular}{|l|c|}
\hline yes & 0 \\
\hline no & 0 \\
\hline don't know & 0 \\
\hline
\end{tabular}


J) Have you used a robo-advisor, i.e. an automated financial advice where you receive an investment suggestion, a sample portfolio, or an investment recommendation based on simple investor profiles and risk tolerances (e.g. at scalable capital, quirion, your bank or savings bank, etc.), during the last two years?

\begin{tabular}{|l|c|}
\hline yes & 0 \\
\hline no & 0 \\
\hline don't know & 0 \\
\hline
\end{tabular}

K) Key investor information documents, so called KIIDs, are provided with various financial products. Have you gotten to know such KIIDs for financial products already?

\begin{tabular}{|l|c|}
\hline yes & 0 \\
\hline no & 0 \\
\hline don't know & 0 \\
\hline
\end{tabular}

L) Suppose that a financial advisor suggested that you invest in a stock. You followed the advice, invested in the stock, and lost money. The financial advisor did not inform you about this risk of a loss. You would like to complain to the supervisory authority that is responsible for such a case. Which authority is responsible for your complaint?

$\square$ Authority (please name):

口। do not know.

M) How would you rate your knowledge in statistics? Grade yourself on a scale from 1 (very good) to 6 (insufficient)

\begin{tabular}{|l|l|l|l|l|l|}
\hline 1 & 2 & 3 & 4 & 5 & 6 \\
\hline 0 & 0 & 0 & 0 & 0 & 0 \\
\hline
\end{tabular}

N) Generally speaking, would you say that most people can be trusted or that one has to be very careful when dealing with other people? Please tick only one of the following answers.

$\square$ Most people can be trusted

$\square$ One has to be very careful when dealing with other people

口। don't know

O) How would you assess your willingness to take risks when investing money?

Please tick a box on a scale from 0 (not willing to take risks) to 10 (very willing to take risks).

The values in between allow you to scale your assessment. 


\begin{tabular}{|l|l|l|l|l|l|l|l|l|l|l|}
\hline 0 & 1 & 2 & 3 & 4 & 5 & 6 & 7 & 8 & 9 & 10 \\
\hline 0 & 0 & 0 & 0 & 0 & 0 & 0 & 0 & 0 & 0 & 0 \\
\hline
\end{tabular}

P) How often do you...

\begin{tabular}{|c|c|c|c|c|c|}
\hline & never & seldomly & sometimes & often & very often \\
\hline $\begin{array}{l}\text {...lend your friends personal items (e.g. books, } \\
\text { your car, your bike, etc.)? }\end{array}$ & 0 & 0 & 0 & 0 & 0 \\
\hline ...lend your friends money? & 0 & o & o & 0 & 0 \\
\hline ...leave the front door unlocked? & 0 & 0 & 0 & 0 & 0 \\
\hline
\end{tabular}

Q) We would like to know which persons, groups, or institutions you trust more or less.

How much do you trust ... [note: the order of the items in this translated version of the questionnaire corresponds to an alphabetical order in the German version]

\begin{tabular}{|c|c|c|c|c|c|}
\hline & no trust at all & little trust & $\begin{array}{l}\text { quite some } \\
\text { trust }\end{array}$ & $\begin{array}{l}\text { a lot of } \\
\text { trust }\end{array}$ & $\begin{array}{l}\text { I don't } \\
\text { know }\end{array}$ \\
\hline ...your colleagues & 0 & 0 & o & o & o \\
\hline ...government agencies & 0 & 0 & o & 0 & 0 \\
\hline ...the federal parliament & 0 & 0 & 0 & 0 & 0 \\
\hline ...the European Union & 0 & 0 & 0 & 0 & 0 \\
\hline ...your own family & 0 & 0 & 0 & 0 & 0 \\
\hline $\begin{array}{l}\text {...the financial supervisory authority } \\
\text { (BaFin) }\end{array}$ & 0 & 0 & 0 & 0 & 0 \\
\hline $\begin{array}{l}\text {...financial service providers (banks, } \\
\text { insurance companies, etc.) }\end{array}$ & 0 & 0 & 0 & 0 & o \\
\hline ...your friends & 0 & 0 & 0 & 0 & 0 \\
\hline ...the courts & 0 & 0 & 0 & 0 & 0 \\
\hline ...labor unions & 0 & 0 & 0 & 0 & 0 \\
\hline ...churches & 0 & 0 & 0 & 0 & 0 \\
\hline ...your neighbors & 0 & o & 0 & o & 0 \\
\hline ...the police & o & 0 & 0 & 0 & 0 \\
\hline ...schools and the education system & 0 & 0 & 0 & 0 & 0 \\
\hline ...consumer organizations & o & 0 & 0 & 0 & 0 \\
\hline ...large corporations & 0 & o & 0 & 0 & 0 \\
\hline ...the press & 0 & 0 & 0 & 0 & 0 \\
\hline
\end{tabular}


R) The following statements might apply more or less to you. Please indicate for each statement to what extent it applies to you personally.

\begin{tabular}{|l|c|c|c|c|c|}
\hline & $\begin{array}{c}\text { does not } \\
\text { apply at } \\
\text { all }\end{array}$ & $\begin{array}{c}\text { does not } \\
\text { really } \\
\text { apply }\end{array}$ & $\begin{array}{c}\text { neither } \\
\text { nor }\end{array}$ & $\begin{array}{c}\text { somewhat } \\
\text { applies }\end{array}$ & $\begin{array}{c}\text { fully } \\
\text { applies }\end{array}$ \\
\hline I take my life in my own hands. & 0 & 0 & 0 & 0 & 0 \\
\hline If I make an effort, I will succeed. & 0 & 0 & 0 & 0 & 0 \\
\hline $\begin{array}{l}\text { Regardless of private or professional life: } \\
\text { My life is largely determined by others. }\end{array}$ & 0 & 0 & 0 & 0 & 0 \\
\hline My plans are often thwarted by fate. & 0 & 0 & 0 & 0 & 0 \\
\hline
\end{tabular}

\section{S) Please try to answer as many of the following questions as possible.}

1. If three employees can wrap three toys in one hour, how many employees are needed to wrap six toys in two hours?

8 employees

2. The work of a student received both the 15th highest and the 15th lowest grade in class. How many students are in the class?

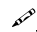
students

3. In an athletics team, tall members are three times more likely to win a medal than short members. This year the team has won 60 medals so far. How many of these have been won by short athletes?

medals

4. A scoop of ice cream and a portion of whipped cream cost 1.20 Euro in total. The scoop of ice cream costs 1.00 Euro more than the whipped cream. How much does the whipped cream cost?<smiles>CCCO</smiles>

5. It takes 5 minutes for five machines to make five bolts, how long would it take for 100 machines to make 100 bolts?

minutes

6. In a lake, there is a patch of lily pads. Every day, the patch doubles size. If it takes 48 days for the patch to cover the entire lake, how long would it take for the patch to cover half of the lake?

days 
T) To what extent do the following statements apply to you?

\begin{tabular}{|l|c|c|c|c|c|}
\hline & $\begin{array}{c}\text { does not } \\
\text { apply at } \\
\text { all }\end{array}$ & $\begin{array}{c}\text { does not } \\
\text { really } \\
\text { apply }\end{array}$ & $\begin{array}{c}\text { neither } \\
\text { nor }\end{array}$ & $\begin{array}{c}\text { somewhat } \\
\text { applies }\end{array}$ & $\begin{array}{c}\text { fully } \\
\text { applies }\end{array}$ \\
\hline I am rather conservative, reserved. & 0 & 0 & 0 & 0 & 0 \\
\hline $\begin{array}{l}\text { I easily trust others, believe in the good in } \\
\text { people. }\end{array}$ & 0 & 0 & 0 & 0 & 0 \\
\hline I am easygoing, prone to laziness. & 0 & 0 & 0 & 0 & 0 \\
\hline $\begin{array}{l}\text { I am relaxed, cannot be disturbed by } \\
\text { stress. }\end{array}$ & 0 & 0 & 0 & 0 & 0 \\
\hline I have only little interest in the arts. & 0 & 0 & 0 & 0 & 0 \\
\hline I am outgoing, sociable. & 0 & 0 & 0 & 0 & 0 \\
\hline I tend to criticize others. & 0 & 0 & 0 & 0 & 0 \\
\hline I perform tasks thoroughly. & 0 & 0 & 0 & 0 & 0 \\
\hline I easily get nervous and insecure. & 0 & 0 & 0 & 0 & 0 \\
\hline I have an active imagination, I am fanciful. & 0 & 0 & 0 & 0 & 0 \\
\hline
\end{tabular}

U) How do you feel at the moment?

\begin{tabular}{|l|c|c|c|c|c|}
\hline I feel... & not at all & a little bit & $\begin{array}{c}\text { to some } \\
\text { degree }\end{array}$ & considerably & extremely \\
\hline$\ldots$ interested & 0 & 0 & 0 & 0 & 0 \\
\hline$\ldots$ depressed & 0 & 0 & 0 & 0 & 0 \\
\hline$\ldots$ nervous & 0 & 0 & 0 & 0 & 0 \\
\hline$\ldots$ determined & 0 & 0 & 0 & 0 & 0 \\
\hline$\ldots$ confused & 0 & 0 & 0 & 0 & 0 \\
\hline$\ldots$ active & 0 & 0 & 0 & 0 & 0 \\
\hline
\end{tabular}

V) How much would you be willing to pay to participate in the following lottery?

Consider the following hypothetical lottery. Imagine a large urn containing 100 balls. In this

urn, there are exactly 50 red balls and the remaining 50 balls are black. One ball is randomly

drawn from the urn. If the ball is red, you win 5,000 euros; otherwise, you win nothing.

What is the maximum price you are willing to pay for a ticket that allows you to participate in this lottery?

$$
\text { Euro }
$$

W) How much would you be willing to pay to participate in the following lottery?

Consider now a situation where there are two urns, A and B. As before, each one has 100 balls, but urn A contains 20 red balls and 80 blacks, while urn B contains 80 reds and 20 blacks. One ball is drawn either from urn $A$ or from urn $B$ (the two events are equally likely). As before, if the ball is red you win 5,000 euros; otherwise, you win nothing.

What is the maximum price you are willing to pay for a ticket that allows you to participate in this lottery?

$$
\text { Euro }
$$

\begin{tabular}{|c|c|c|c|c|c|}
\hline & $\begin{array}{c}\text { do not } \\
\text { agree at } \\
\text { all }\end{array}$ & $\begin{array}{l}\text { do not } \\
\text { really } \\
\text { agree }\end{array}$ & $\begin{array}{c}\text { neither } \\
\text { nor }\end{array}$ & $\begin{array}{c}\text { somewhat } \\
\text { agree }\end{array}$ & $\begin{array}{l}\text { completely } \\
\text { agree }\end{array}$ \\
\hline $\begin{array}{l}\text { In uncertain times, I usually expect the } \\
\text { best. }\end{array}$ & o & o & $\circ$ & $\circ$ & $\circ$ \\
\hline It is easy for me to relax. & o & o & o & 0 & 0 \\
\hline If something can go wrong for me, it will. & o & o & o & o & o \\
\hline I am always optimistic about my future. & 0 & o & ○ & 0 & 0 \\
\hline I enjoy my friends a lot. & 0 & o & $\circ$ & 0 & 0 \\
\hline It is important to me to keep busy. & $\circ$ & o & $\circ$ & 0 & 0 \\
\hline I hardly ever expect things to go my way. & o & o & $\circ$ & 0 & 0 \\
\hline I do not get upset too easily. & o & o & ○ & 0 & 0 \\
\hline $\begin{array}{l}\text { I rarely count on good things happening to } \\
\text { me. }\end{array}$ & o & o & $\circ$ & 0 & $\circ$ \\
\hline $\begin{array}{l}\text { Overall, I expect more good things to } \\
\text { happen to me than bad. }\end{array}$ & o & o & 0 & $\circ$ & o \\
\hline
\end{tabular}

X) Please indicate how strongly you agree with the following statements. 
Y) Please take a look at the following information provided by InvestmentRobot and answer the subsequent questions.

InvestmentRobot is the ideal solution for investors who do not have much time or expertise to adapt their investments to the developments in financial markets:

\section{Determine an individual investment strategy}

The individual risk capacity (What losses can I afford?) and risk preference (How much risk am I willing to take?) are crucial for each form of investment. Both are determined by our investment assistant and used to determine the suitable portfolio.

\section{Intelligent Investments - Focus on advantageous ETFs}

All our investment strategies are implemented with intelligently composed and broadly diversified ETFs. ETFs are exchange traded funds. Their performance corresponds to the performance of an index, e.g. the DAX. When investing in an ETF, you as investor participate in the development of an entire market. Your advantage: You save a major portion of the usual mutual fund fees and, therefore, considerably increase your return. Compared to an investment in single assets, ETFs offer risk diversification across a multitude of assets already for small investment amounts, reducing the risk of losses.

\section{Diversification}

InvestmentRobot invests worldwide and broadly across different asset classes in ETFs. The diversification reduces the portfolio's susceptibility to fluctuations, allows to capitalize on opportunities, and to reduce individual risks.

\section{Optimal return}

We have developed a suitable, fine balanced system of tailor-made investment strategies that correspond to each customer's investment personality and corresponding return-risk targets. They rely on an individual mix of bonds and stocks with a stock ratio ranging between 10 percent and 100 percent. The realized return is convincing:

\begin{tabular}{|c|c|c|c|c|c|c|c|c|c|c|}
\hline \multirow[b]{2}{*}{$\begin{array}{l}\text { time } \\
\text { period }\end{array}$} & \multicolumn{10}{|c|}{$\begin{array}{l}\text { Returns of a mix of stocks and bonds with the following ratio of stocks / bonds in percent } \\
\text { Returns per mix of stocks and bonds per time period }\end{array}$} \\
\hline & $\begin{array}{c}10 \% / \\
90 \%\end{array}$ & $\begin{array}{c}20 \% \text { I } \\
80 \%\end{array}$ & $\begin{array}{c}30 \% / \\
70 \%\end{array}$ & $\begin{array}{l}40 \% / \\
60 \%\end{array}$ & $\begin{array}{c}\mathbf{5 0} \% \text { I } \\
\mathbf{5 0 \%}\end{array}$ & $\begin{array}{c}60 \% / \\
40 \%\end{array}$ & $\begin{array}{c}70 \% \text { I } \\
30 \%\end{array}$ & $\begin{array}{c}80 \% l \\
20 \%\end{array}$ & $\begin{array}{c}90 \% / \\
10 \%\end{array}$ & $\begin{array}{c}100 \% / \\
0 \%\end{array}$ \\
\hline $\begin{array}{l}06 / 30 / 19- \\
06 / 30 / 18\end{array}$ & $1.56 \%$ & $1.67 \%$ & $1.78 \%$ & $1.90 \%$ & $2.00 \%$ & $2.15 \%$ & $2.27 \%$ & $2.36 \%$ & $2.49 \%$ & $2.57 \%$ \\
\hline $\begin{array}{l}06 / 30 / 18- \\
06 / 30 / 17\end{array}$ & $0.16 \%$ & $0.91 \%$ & $1.61 \%$ & $2.35 \%$ & $3.09 \%$ & $3.83 \%$ & $4.55 \%$ & $5.27 \%$ & $6.01 \%$ & $6.57 \%$ \\
\hline $\begin{array}{l}06 / 30 / 17- \\
06 / 30 / 16\end{array}$ & $1.20 \%$ & $2.96 \%$ & $4.71 \%$ & $6.44 \%$ & $8.18 \%$ & $9.91 \%$ & $11.70 \%$ & $13.50 \%$ & $15.28 \%$ & $16.44 \%$ \\
\hline $\begin{array}{l}06 / 30 / 16- \\
06 / 30 / 15\end{array}$ & $2.04 \%$ & $0.81 \%$ & $0.01 \%$ & $-0.78 \%$ & $-1.48 \%$ & $-2.43 \%$ & $-3.30 \%$ & $-3.85 \%$ & $-4.49 \%$ & $-5.62 \%$ \\
\hline $\begin{array}{l}06 / 30 / 15- \\
06 / 30 / 14\end{array}$ & $2.27 \%$ & $3.76 \%$ & $5.39 \%$ & $7.02 \%$ & $8.88 \%$ & $10.12 \%$ & $11.61 \%$ & $13.09 \%$ & $14.73 \%$ & $15.76 \%$ \\
\hline
\end{tabular}

Fair costs

Issue surcharges do not exist, neither do hidden fees. This guarantees that we are independent while we select the investments suitable for you!

\section{Comfortable investing}




\title{
Appendix
}

\section{Rebalancing}

Markets develop in different directions from time to time. Consequently, your portfolio will not correspond to your initial target allocation and the risk may shift over time. To prevent this, we monitor your portfolio continuously and rebalance assets when necessary. More specifically, we sell ETFs whose portfolio share has become too high and buy underweighted ETFs instead. At least once a year we automatically conduct a rebalancing to reestablish the initial investment ratios. Moreover, if one of the asset classes diverges by more than 10 percent from its target weight in the meantime, we also will reestablish the initial investment ratios.

\begin{abstract}
Advantages of asset management - Prevention of irrational behavior
Instead of deciding rationally and following a clear strategy, investor often behave too impulsively, myopically and too procyclically. In upward phases the inclination to firstly observe skeptically and missing the price increase is dominating. In this sense, less mindful investors invest when they are convinced of an upswing - in most cases too late and at too high prices. A suddenly appearing downswing then catches the investor on the wrong foot; and if the downtrend continues, the financial and psychological tolerance for suffering soon runs out. When completely frustrated, the investor sells - often at the rock bottom.

An emotional investor, therefore, acts procyclically and improvidently buys stocks at high prices and sells them frustrated and scared at low prices. In this manner, a lot of money is burned in the long run! Instead of impulsively and procyclically trying to catch up with every short-term trend, it is essential to keep calm.
\end{abstract}

\section{Facts and Figures - simply convincing}

- The InvestmentRobot-portfolio is run online: Performance reports and account statements are provided online in the online-inbox.

- Competitive pricing: You only pay a relative investment management fee: .04 \% per month (.48\% p.a. with monthly settlement). All specifications are inclusive of taxes. - InvestmentRobot is under supervision of the Federal Financial Supervisory Authority (BaFin), Marie-Curie-Str. 24-28, 60439 Frankfurt am Main (website: www.bafin.de). - InvestmentRobot is the winner (overall grade: 2.0) of the recent Stiftung Warentest test on robo-advisors and performance champion of brokervergleich.de

\section{Investing with good financial judgement - Opportunities and Risks}

Financial investments are always subject to risks. At this point, we

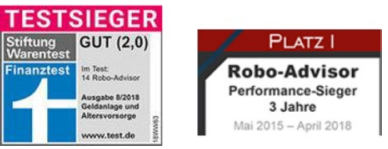
would like to refer to some relevant risks associated with financial investments in general, but also with the products we use.

\section{INFLATION RISK}

Investments with low risks usually offer relatively low chances of high returns. The returns can even be so low that under circumstances the inflation rate is higher than the earned interest. Measured against the purchasing power, losses are possible with a relatively safe investment, even if one gets the money back including all agreed-upon interest payments.

\section{BOND RISK}

The risks of a bond strongly depend on the solvency of the bond issuer, which is responsible for the repayment. This can be a bank, a government, or a company. In general, it is considered a relatively low to medium risk though. Exceptions are often bonds of mediumsized businesses and developing countries.

\section{STOCK RISK}

Investments in stocks are generally considered as being in the upper part of the risk scale. This results from the possibility of strong short-term up- and down-movements. 
You have 1,000 Euros per year available for investments. Would you invest with InvestmentRobot?

$\square$ No

If no:

How much of the 1,000 Euros would you invest in stocks and bonds on your own (without InvestmentRobot)? Euros

$\square$ Yes

If yes:

How much of the 1,000 Euros would you invest with InvestmentRobot?

Euros

How much of the remaining money would you invest on your own (without InvestmentRobot) in the following assets?

Liquidity provisions

Euros

Financial investment with low risk and low return, e.g. savings certificates,

fixed-term deposits

Euros

Globally diversified bond index funds (ETF)

Euros

Globally diversified stock index funds (ETF)

Euros

Open-end or closed-end real estate funds

Euros

Bond mutual funds

Euros

Stock mutual funds

Euros

Balanced mutual funds that invest in stocks, bonds and other assets

$$
\text { E Euros }
$$

Individual corporate or government bonds

Euros

Individual stocks

Euros

Others

Euros

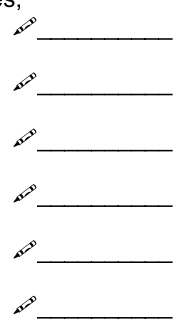

Which proportions of stocks and bonds in percent should your investment with InvestmentRobot include?

\begin{tabular}{|c|c|c|c|c|c|c|c|c|c|}
\hline $10 \%$ stocks $/$ & $20 \% /$ & $30 \% /$ & $40 \% /$ & $50 \% /$ & $60 \% /$ & $70 \% /$ & $80 \% /$ & $90 \% /$ & $100 \% /$ \\
$90 \%$ bonds & $80 \%$ & $70 \%$ & $60 \%$ & $50 \%$ & $40 \%$ & $30 \%$ & $20 \%$ & $10 \%$ & $0 \%$ \\
\hline 0 & 0 & 0 & 0 & 0 & 0 & 0 & 0 & 0 & 0 \\
\hline
\end{tabular}

What do you think the value of your investment with InvestmentRobot will be in one year? 8 Euros 
Funding Open Access funding enabled and organized by Projekt DEAL.

\section{Declarations}

\section{Conflicts of interest/Competing interests None.}

Availability of data and material Corresponding author provides data upon request.

Code availability Not applicable.

Open Access This article is licensed under a Creative Commons Attribution 4.0 International License, which permits use, sharing, adaptation, distribution and reproduction in any medium or format, as long as you give appropriate credit to the original author(s) and the source, provide a link to the Creative Commons licence, and indicate if changes were made. The images or other third party material in this article are included in the article's Creative Commons licence, unless indicated otherwise in a credit line to the material. If material is not included in the article's Creative Commons licence and your intended use is not permitted by statutory regulation or exceeds the permitted use, you will need to obtain permission directly from the copyright holder. To view a copy of this licence, visit http://creativecommons.org/licenses/by/4.0/.

\section{References}

Abreau M, Mendes V (2012) Information, overconfidence and trading: Do the sources of information matter? J Econ Psychol 33(4):868-881

Alemanni B, Angelovski A, Di Cagno D, Galliera A, Linciano N, Marazzi F, Soccorso P (2020) Do investors rely on robots? Evidence from an experimental study. CONSOB Fintech Series No. 7, available at SSRN: https://ssrn.com/abstract=3697232. Accessed 10/02/2021

Barberis N, Thaler R (2003) A Survey of behavioral finance. In: Konstantinides G, Harris M, Stulz R (ed) Handbook of the Economics of Finance 1B, pp 1053-1123

Barnett T, Pearson A, Pearson R, Kellermanns F (2015) Five-factor model personality traits as predictors of perceived and actual usage of technology. Eur J Inf Syst 24(4):374-390

Behrenbruch K, Söllner M, Leimeister J, Schmidt L (2013) Understanding Diversity - The Impact of Personality on Technology Acceptance. Hum Comput Interact - INTERACT 2013: 306-313

Breen R (1996) Regression models: censored, sample-selected, or truncated data. Sage, Thousand Oaks

Camerer C, Hogarth R (1999) The effects of financial incentives in experiments: a review and capitallabor production framework. J Risk Uncertain 19(1-3):7-42

Campbell J, Ramadorai T, Ranish B (2014) Getting Better or Feeling Better? How Equity Investors Respond to Investment Experience. NBER Working Paper No. 20000

Corgnet B, Desantis M, Porter D (2018) What Makes a Good Trader? On the Role of Intuition and Reflection on Trader Performance. J Finance 73(3):1113-1137

Cummings RG, Elliott S, Harrison G, Murphy J (1997) Are hypothetical referenda incentive compatible? J Political Economy 105(3):609-621

D’Acunto F, Rossi A (2020) Robo-Advising. CESifo Working Paper No. 8225, available at SSRN: https:// ssrn.com/abstract $=3578259$. Accessed 10/02/2021

D'Acunto F, Prabhala N, Rossi A (2019) The Promises and Pitfalls of Robo-Advising. Rev Financ Stud 32(5): $1983-2020$

Deaves R, Lüders E, Luo G (2009) An Experimental Test of the Impact of Overconfidence and Gender on Trading Activity. Rev Financ 13(3):555-575

Dohmen T, Falk A, Huffman D, Sunde U, Schupp J, Wagner GG (2011) Individual Risk Attitudes: Measurement, Determinants and Behavioral Consequences. J Eur Econ Assoc 9(3):522-550

Fehr E, Fischbacher U, von Rosenbladt B, Schupp J, Wagner GG (2002) A Nation-Wide Laboratory Schmollers Jahrb 122:519-542

Fisch J, Labouré M, Turner J (2019) The Emergence of the Robo-Advisor. In: Agnew J, Mitchell O (ed) The Disruptive Impact of FinTech on Retirement Systems, pp 13-37

Foerster S, Linnainmaa J, Melzer B, Previtero A (2017) Retail financial advice: Does one size fit all? J Finance 72(4):1441-1482 
Frederick S (2005) Cognitive Reflection and Decision Making. J Econ Perspect 19(4):25-42

Glaesmer H, Hoyer J, Klotsche J, Herzberg P (2008) Die deutsche Version des Life-Orientation-Tests (LOT-R) zum dispositionellen Optimismus und Pessimismus. Zeitschrift Für Gesundheitspsychologie 16(1):26-31

Glaser M, Langer T, Reynders J, Weber M (2007) Scale Dependence of Overconfidence in Stock Market Volatility Forecasts, Working Paper

Graham JR, Harvey CR, Huang H (2009) Investor Competence, Trading Frequency, and Home Bias. Manag Science 55(7):1094-1106

Guiso L, Sapienza P, Zingales L (2008) Trusting the Stock Market. J. Finance 63(6):2557-2600

Hohenberger C, Lee C, Coughlin J (2019) Acceptance of robo-advisors: Effects of financial experience, affective reactions, and self-enhancement motives. Financial Plan. Rev. 2(2):e1047

Horn M, Oehler A, Wendt S (2020) FinTech for Consumers and Retail Investors: Opportunities and Risks of Digital Payment and Investment Services. In: Walker T, Gramlich D, Bitar M, Fardnia P (ed) Ecological, Societal, and Technological Risks and the Financial Sector, pp 405-421

Horn M, Oehler A (2020) Automated Portfolio Rebalancing: Automatic Erosion of Investment Performance? J Asset Manag 21(6):489-505

Inderst R, Ottaviani M (2009) Misselling through Agents. American Economic Review 99(3):883-908

Kaustia M, Conlin A, Luotonen N (2019) What drives the heterogeneity in portfolio choice? The role of institutional, traditional, and behavioral factors. Working Paper available at SSRN:https://papers.ssrn. com/sol3/papers.cfm?abstract_id=2845963. Accessed 10/02/2021

Kovaleva A, Beierlein C, Kemper C, Rammstedt B (2012) Eine Kurzskala zur Messung von Kontrollüberzeugung: Die Skala Internale-Externale- Kontrollüberzeugung-4 (IE-4). Gesis Working Papers, Mannheim

Krohne H, Egloff B, Kohlmann C, Tausch A (1996) Untersuchung mit einer deutschen Version der „Positive and Negative Affect Schedule“ (PANAS). Diagnostica 42(2):139-156

Lee C, Ward C, Raue M, D'Ambrosio L, Coughlin JF (2017) Age differences in acceptance of self-driving cars: A survey of perceptions and attitudes. International Conference on Human Aspects of IT for the Aged Population

Linnainmaa J, Melzer B, Previtero A (2020) The Misguided Beliefs of Financial Advisors. J Finance forthcoming

Nicolosi G, Peng L, Zhu N (2009) Do Individual Investors Learn from Their Trading Experience. J Financ Markets 12(2):317-336

Nosic A, Weber M (2010) How Riskily Do I Invest? The Role of Risk Attitudes, Risk Perceptions, and Overconfidence. Decis Anal 7:282-301

Oehler A, Wendt S (2018) Trust and Financial Services: The Impact of Increasing Digitalisation and the Financial Crisis. In: Sigurjónsson TO, Schwarzkopf D, Bryant M (eds) The Return of Trust? Institutions and the Public after the Icelandic Financial Crisis, Emerald, pp 195-211

Oehler A, Horn M, Wedlich F (2018a) Young adults' subjective and objective risk attitude in financial decision making: Evidence from the lab and the field. Rev Behav Finance 10(3):274-294

Oehler A, Horn M, Wendt S, Reisch L, Walker T (2018b) Young adults and their finances: An international comparative study on applied financial literacy. Econ Notes 47(2-3):305-330

Oehler A, Wendt S, Wedlich F, Horn M (2018c) Investors' Personality Influences Investment Decisions: Experimental Evidence on Extraversion and Neuroticism. J Behav Finance 19(1):30-48

Oehler A, Wanger HP (2020) Household Portfolio Optimization with XTFs? An Empirical Study Using the SHS-base. Res. Int. Bus. Finance, forthcoming. https://doi.org/10.1016/j.ribaf.2019.101103

Oehler A, Wedlich F, Wendt S, Horn M (2020) Does personality drive price bubbles? Stud Econ Finance 38(3):619-639

Oehler A, Horn M, Wendt S (2021) Information Illusion: Different Amounts of Information and Stock Price Estimates. Working Paper accepted at Annual Meeting of American Economic Association, January $3-5,2021$

Primi C, Morsanyi K, Chiesi F, Donati M, Hamilton J (2016) The Development and Testing of a New Version of the Cognitive Reflection Test Applying Item Response Theory (IRT). J Behav Decis Mak 29(5):453-469

Puri M, Robinson D (2007) Optimism and economic choice. J Financial Economics 86(1):71-99

Rammstedt B, Kemper C, Klein M, Beierlein C, Kovaleva A (2012) Eine kurze Skala zur Messung der fünf Dimensionen der Persönlichkeit: Big-Five-Inventory-10 (BFI-10). Gesis Working Papers 2012/23

Rossi A, Utkus S (2020a) The Needs and Wants in Financial Advice: Human versus Robo-advising. Working Paper available at SSRN: https://papers.ssrn.com/sol3/papers.cfm?abstract_id=3759041. Accessed $10 / 02 / 2021$ 
Rossi A, Utkus S (2020b) Who Benefits from Robo-advising? Evidence from Machine Learning. Working Paper available at SSRN: https://doi.org/10.2139/ssrn

Seru A, Shumway T, Stoffman N (2010) Learning by Trading Rev Financ Stud 23(2):705-739

SOEP (2003) SOEP 2003 - Erweiterter Pretestbericht zum Befragungsjahr 2003 (Welle 20) des Soziooekonomischen Panels - Fragebogen und Verhaltensexperiment

Statista (2020) Robo-Advisors worldwide, available at https://www.statista.com/outlook/337/100/robo-advis ors/worldwide. Accessed 10/02/2021

Van Rooij M, Lusardi A, Alessie R (2011) Financial Literacy and stock market participation. J Financial Economics 101(2):449-472

Von Gaudecker HM (2015) How Does Household Portfolio Diversification Vary with Financial Literacy and Financial Advice. J Financ 70(2):489-506

Yang A (2013) Decision Making for Individual Investors: A Measurement of Latent Difficulties. J Financ Serv Res 44:303-329

Publisher's Note Springer Nature remains neutral with regard to jurisdictional claims in published maps and institutional affiliations. 